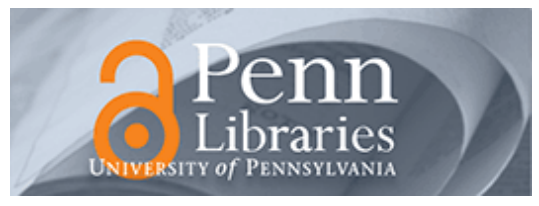

University of Pennsylvania

ScholarlyCommons

Management Papers

Wharton Faculty Research

$12-2014$

\title{
FDI Spillovers and Industrial Policy: The Role of Tariffs and Tax Holidays
}

Luosha Du

Ann Harrison

University of Pennsylvania

Gary Jefferson

Follow this and additional works at: https://repository.upenn.edu/mgmt_papers

Part of the Business Administration, Management, and Operations Commons, and the Taxation Commons

Recommended Citation

Du, L., Harrison, A., \& Jefferson, G. (2014). FDI Spillovers and Industrial Policy: The Role of Tariffs and Tax Holidays. World Development, 64 366-383. http://dx.doi.org/10.1016/j.worlddev.2014.06.005

This paper is posted at ScholarlyCommons. https://repository.upenn.edu/mgmt_papers/148

For more information, please contact repository@pobox.upenn.edu. 


\title{
FDI Spillovers and Industrial Policy: The Role of Tariffs and Tax Holidays
}

\begin{abstract}
This paper examines how industrial policy - specifically tariff liberalization and tax subsidies - affects the magnitude and direction of FDI spillovers. We examine these spillover effects across the diverse ownership structure of China's manufacturing sector for 1998 through 2007. We find that tariff reforms, particularly tariff reductions associated with China's WTO ascension, increased the productivity impacts of FDI's backward spillovers. Tax policy - both corporate income and VAT subsidies - has seemingly drawn FDI into strategic industries that spawn significant vertical spillovers. We conclude that liberalization measures during the critical 1998-2007 period on balance served to enhance productivity growth in Chinese industry.
\end{abstract}

Keywords

foreign direct investment, industrial policy, manufacturing productivity, China, spillovers

Disciplines

Business Administration, Management, and Operations | Taxation 
NBER WORKING PAPER SERIES

FDI SPILLOVERS AND INDUSTRIAL POLICY: THE ROLE OF TARIFFS AND TAX HOLIDAYS

\author{
Luosha $\mathrm{Du}$ \\ Ann Harrison \\ Gary Jefferson \\ Working Paper 16767 \\ http://www.nber.org/papers/w16767
NATIONAL BUREAU OF ECONOMIC RESEARCH
1050 Massachusetts Avenue
Cambridge, MA 02138
February 2011

This paper previously circulated as "Do Institutions Matter for FDI Spillovers? The Implications of China's 'Special Characteristics'." The authors gratefully acknowledge suggestions by the editor and two anonymous referees, who have significantly improved this paper. We are also grateful to the conference organizers at Fudan University, including the contributions of Peter Petri. We would also like to thank Justin Lin, Max Auffhammer, and Jeremy Magruder for their valuable comments, as well as seminar participants at Yale University, the Wharton Management Department at the University of Pennsylvania, and the World Bank. This work is partially based on work supported by the National Science Foundation under grant No. 0519902, and through a grant from the Research Support Budget of the World Bank. The views expressed herein are those of the authors and do not necessarily reflect the views of the National Bureau of Economic Research.

NBER working papers are circulated for discussion and comment purposes. They have not been peerreviewed or been subject to the review by the NBER Board of Directors that accompanies official NBER publications.

(C) 2011 by Luosha Du, Ann Harrison, and Gary Jefferson. All rights reserved. Short sections of text, not to exceed two paragraphs, may be quoted without explicit permission provided that full credit, including $(\subset$ notice, is given to the source. 
FDI Spillovers and Industrial Policy: The Role of Tariffs and Tax Holidays

Luosha Du, Ann Harrison, and Gary Jefferson

NBER Working Paper No. 16767

February 2011, Revised June 2014

JEL No. F2,F23

\begin{abstract}
This paper examines how industrial policy - specifically tariff liberalization and tax subsidies - affects the magnitude and direction of FDI spillovers. We examine these spillover effects across the diverse ownership structure of China's manufacturing sector. Using this approach, we control for policies that are likely to be correlated with both firm-level productivity and industry FDI, thereby limiting the problem of omitted variables and bias associated with estimating the impacts of FDI spillovers. During 1998-2007, the span of our Chinese firm-level data set, both tariffs and FDI tax holidays changed dramatically. Our results highlight the efficacy of vertical FDI spillovers. We find that tariff reforms, particularly tariff reductions associated with China's WTO ascension, increased the productivity impacts of FDI's backward spillovers. Tax policy - both corporate income and VAT subsidies - has seemingly drawn FDI into strategic industries that spawn significant vertical spillovers. We conclude that liberalization measures during the critical 1998-2007 period on balance served to enhance productivity growth in Chinese industry.
\end{abstract}

Luosha Du

Department of Agricultural

and Resource Economics

UC Berkeley

Giannini Hall

Berkeley, California 94720

luosha@berkeley.edu

Ann Harrison

Management Department

The Wharton School

University of Pennsylvania

2016 Steinberg Hall-Dietrich Hall

3620 Locust Walk

Philadelphia, PA 19104-6370

and NBER

annh@wharton.upenn.edu
Gary Jefferson

Brandeis University

Economics Department

Waltham, Ma. 02254

jefferson@brandeis.edu 
The Chinese government intervenes extensively to promote industrialization, relying on a range of policy instruments. In this paper, we examine three such policies that affect the magnitude and direction of the spillovers from foreign direct investment. These policies are the ownership structure of the enterprise system, including direct state-ownership and accommodations to FDI, and tariffs and tax subsidies, both of which serve the purpose of promoting foreign investment in key sectors. In this paper, we extend our understanding of how each of these policies - state and foreign ownership, tariffs and trade reform, and tax incentives - operates through intra- and/or inter-industry FDI spillovers to affect the performance of Chinese-based manufacturing firms.

Incorporating these policy instruments into the analysis of FDI spillovers addresses two objectives. The first is to assess the effectiveness of different forms of industrial policy, including their indirect effects. A second purpose is to control for possible bias associated with econometric estimates of FDI spillovers resulting from the omission of industrial policies that are systematically correlated with FDI clusters. These FDI clusters include both within- industry clusters spurring horizontal spillovers or between-industry FDI clusters leading to vertical upstream or downstream effects. Given the likely interactions of industrial policy and FDI, studies of FDI spillovers should attempt to control for the direct and indirect impacts of these policies.

The period between 1998 and 2007 witnessed many policy shifts as China altered and experimented with a range of industrial policies. Tens of thousands of state-owned enterprises changed ownership or were liquidated. At the end of 2001, China became a member of the World Trade Organization (WTO). Average tariffs on manufacturing in China, which stood at 
43 percent in 1994, following China's accession to the WTO fell to 9.4 percent by $2004{ }^{4}$ FDI inflows accelerated, and by the end of the period China was one of the top destinations for foreign investment. Over these ten years, many foreign investors in China faced much lower corporate tax rates than domestic enterprises. Before 2008, foreign investors received a 15 percent corporate tax rate while domestic enterprises faced a regular 33 percent corporate tax rate $^{5}$. This policy of promoting foreign invested firms and other favored firms was only discontinued in 2008. It is difficult to imagine that these substantial changes have not, both directly and through their impact on FDI, affected the productivity performance of Chinese manufacturing.

Other countries have received extensive FDI within the context of state- and foreignownership, tariff protection, and tax incentives. However, probably no country to the extent of China has sponsored such an active range of industrial policies in combination with as heterogeneous a group of enterprise types. China's enterprise system includes an extensive system of state-owned enterprises, including those with a mix of state and foreign ownership; foreign-owned firms distinguish overseas investment from Hong Kong, Macao, and Taiwan versus that from other areas including the OECD countries. Patterns of tariff protection and liberalization, as well as the fabric of tax subsidies, are likely to be interconnected with patterns of enterprise ownership.

Our results suggest that the trade reforms and tax policies adopted by China during the 10 years of our sample period increased the gains from incoming FDI. Our first result is that both tariff reductions and China's entry into the WTO increased the gains from vertical FDI spillovers.

\footnotetext{
${ }^{4}$ Naughton (2007), Ch. 16.

5 However, the government adjusted this preferential policy in 2008. Beginning Jan 1, 2008, the following corporate tax policy for foreign-invested firms came into effect: foreign-invested firms that previously received preferential corporate tax rates would return to the regular tax rate within 5 years. In 2008, the tax rate increased from $15 \%$ to $18 \%$; in 2009 , the rate further increased to $20 \%$; in 2010 , the corporate tax rate rose to $22 \%$ and finally reached $25 \%$ in 2012.
} 
By interacting measures of tariff reform and WTO entry with our foreign investment measures, we find significant increases in the benefits from FDI after trade reform, especially for backward linkages. Second, we find that foreign investors who received corporate tax breaks transmitted larger externalities to domestic enterprises. Third, the evidence suggests that pairing foreign firms with SOEs led to gains for SOE partners that generally exceeded gains for other domestic firms.

We suggest a set of reasons for the robustness of downstream FDI and backward spillovers; some of these are general, while some are specific to China. Recent analyses of vertical FDI spillovers for other countries (see the survey in Harrison and Rodriguez Clare (2010)) have emphasized the importance of backward linkages from domestic suppliers to foreign buyers. Strong backward linkages were present in studies of Lithuania, Great Britain, and Indonesia, for example. Other conditions are specific to China: formal and informal "technology for markets" programs have emphasized the provision of knowledge in exchange for market access in a variety of sectors such as automobiles where the acquisition of knowledge by local suppliers is a key constraint.

While the focus of this paper is on the interaction between FDI spillovers and domestic policies, the stand-alone results for ownership and spillover effects are themselves of interest. Horizontal spillovers, which measure spillovers from foreign to domestic firms in the same sector, are robust only for firms with foreign partners and for SOEs. Forward linkages, which include positive spillovers from upstream foreign suppliers to downstream firms, are generally significant. Backward linkages, which measure linkages from domestic suppliers to foreign buyers, are largest in magnitude and significant once we control for trade policies and their interaction with FDI. 
In addition to measuring the impact of formal tariff reductions on final goods and on inputs, we also explore the impact of China's entry into the WTO at the end of 2001. Tariff changes do not capture the important shift in market access to foreign markets induced by China's WTO entry. Tariff changes also do not capture other changes associated with WTO membership, such as reductions in non-tariff barriers and domestic content laws. To capture this, we also explore the impact of a WTO dummy on firm performance. For all enterprises except the foreign invested firms, WTO entry was associated with a very large and significant improvement in performance. The evidence suggests that market access to foreign markets was a more important driver of firm performance, as measured by TFP growth, than internal tariff reductions.

We also explore the differential impact of tax subsidies bestowed on foreign investors. If the Chinese government correctly targets, through tax concessions, those sectors and firms with greater potential for creating spillovers, we would expect stronger linkages associated with tax breaks. We do, in fact, find statistically significant evidence of stronger FDI productivity externalities associated with sectors and firms that received tax breaks.

We examine these connections in the five sections that follow. Section II reviews the existing literature and Section III lays out the analytical framework of the paper. Our data set, described in Section IV, consists of a comprehensive panel of firm-level data constructed from extensive annual firm surveys covering the period 1998-2007. We use these data to implement our econometric strategy described in Section V. Section VI describes and analyzes the key results of the analysis, and Section VII presents the concluding comments.

\section{Literature Review}


China's transition from a highly centralized, monopolistic trade regime with extensive import and export controls began at the end of 1978. Figure 1 shows that the share of trade (exports plus imports) in GDP for China was less than 10 percent in the 1970s, but increased rapidly as the regime liberalized. By the mid-1990s, the share of trade in GDP had reached over 40 percent. Naughton (1996) documents the transition to a more open trade and foreign investment regime from 1978 onwards. ${ }^{6}$ One important feature of the reforms was its dualistic nature, similar to other types of dual track reforms introduced in China the last several decades. The dualism was characterized by a rapidly expanding system of export processing operating alongside a fairly protected domestic economy.

In 1980 the government established the first four Special Economic Zones and extended these to 14 coastal cities in 1984 (Brandt, Van Biesebroeck, Wang, and Zhang, 2012). Foreign investment inflows were encouraged to bring in capital, and the government began a policy of sometimes explicit and other times implicit bargaining to grant domestic market access to foreign companies in exchange for technological know-how. Duty free importation was also allowed outside special zones, particularly for targeted foreign firms.

As Figure 1 shows, beginning in the mid-1990s China's integration into the global economy accelerated, with trade growing to 70 percent of GDP right before the financial crisis in 2007. One factor that has facilitated the continued growth in trade is the spectacular rise in inward foreign investment, which is documented in Figure 2. Major reforms to encourage incoming foreign investment were introduced in 1986 and 1991. Inducements to foreign investors included duty drawbacks, tariff exemptions, subsidies, infrastructure provisions, and tax

\footnotetext{
${ }^{6}$ Elements of the trade and investment reforms included exchange rate devaluation, relaxing rules on currency convertibility, increasing the number of foreign trade corporations from twelve national monopolies to many thousands, reducing non-tariff barriers, and gradually reducing tariffs and freeing up import prices.
} 
holidays.

Numerous papers have examined the existence and magnitude of FDI spillovers in China.

Jefferson and Miao (2014) review much of the literature and try to explain the lack of consistency regarding the research findings concerning China's FDI spillovers. Their central finding, resulting from their review of 16 Chinese FDI spillover papers, is that the multiplicity of data sources and research methodologies render impossible an effective comparison of the results. These differences include the use of value added versus gross output measures of factor productivity; some analyses are derived with the assumption of constant returns to scale; others are not. Moreover, while the earlier papers focused largely on horizontal, intra-industry spillovers, more recent papers have included vertical, forward and backward, as well as horizontal spillovers. Different papers invariably impose different controls. Some papers control, often in different ways, for China's extensive set of ownership types; some seek to identify the channels through which FDI might affect host firm productivity, such as labor market movement and trade; most do not. With respect to econometric strategy, some use industry, region or province, or firm-level fixed effects; others do not. These are but some of the differences that Jefferson and Miao identify which frustrate efforts to arrive at robust consensus conclusions regarding the body of research on Chinese FDI spillovers. ${ }^{7} \quad$ By

7 Two of the papers reviewed by Jefferson and Miao (2014) use the above size firm-level data set and incorporate both horizontal and vertical FDI spillover possibilities, both of which are used in this paper. These papers are Lin, Liu, and Zhang (2009) and Girma, Gong, and Gord (2009). The samples drawn from those papers both use shorter time horizons than we use in this paper. Lin et al (2009) distinguish between spillover effects originating from investment from Hong Kong, Macao, and Taiwan (HMT) and foreign, non-HMT investment. In either case, they find strong and robust vertical spillover effects on both state-owned firms and non-state firms. Girma et al (2009) examine the impact of FDI spillovers, both horizontal and vertical, on new product innovation rather than TFP. They conclude that FDI clusters have negative impacts on innovation in SOEs. However, for a subsample of the SOEs - those that export, invest in human capital or R\&D, or have prior innovation experience (i.e., the more technologically advanced SOEs) - Girma et al find that FDI has positive impacts on their innovation activity. A third paper by Hu and Jefferson (2002) that looks only at horizontal spillovers finds that SOEs are more susceptible to negative spillover effects than non-SOEs. Thus, while there is no common core findings, stitching the various findings together, this slice of the literature concludes that the spillover impacts across different ownership types are varied, depending on the direction of the spillover. SOEs, particularly those that are more technologically sophisticated, are likely to benefit from vertical FDI spillovers. Less technologically advanced SOEs appear not to benefit from horizontal spillovers. 
introducing tariff and tax policy into the analysis, this paper only extends the variety of research approaches. However, we will be able to compare FDI spillover impacts on different ownership types with such attention given in other papers.

None of the papers in the Jefferson and Miao review controls for tariffs or tax subsidies. However, outside of China, we do find an extensive literature that explores the role of trade liberalization and its impact on productivity for both developed and developing countries. While this literature is reviewed in detail in Harrison and Rodriguez-Clare (2010), we discuss some of the most relevant papers here. Recent papers on trade liberalization include Trefler (2004) for Canada and Bustos (2011) for Argentina. Trefler (2004) explores the impact of tariff reductions on Canadian manufacturing after the passage of the North American Free Trade Agreement (NAFTA). Trefler finds that in the short run employment fell on average 5 percent and up to 12 percent in the most heavily affected sectors that had large tariff declines. He also finds large increases in Canadian labor productivity as a result of the tariff reductions, of 14 to 15 percent. Trefler concludes that parts of the labor force experienced significant short term losses despite the longer term efficiency gains, and that this explains in part the public's disaffection with trade reform. Bustos (2011) uses a similar event: the reduction of tariffs under the MERCOSUR agreement, to explore the impact on Argentina's firms. She finds that firms facing tariff cuts increased their investments in both process and product technological upgrading.

One new area of research seeks to disentangle the effects of input and output tariffs. Illustrative of this research is Amiti and Konings (2007), who use Indonesian manufacturing census data to show that the effect of reducing input tariffs significantly increases productivity, and that this effect is much higher than that of reducing output tariffs. New research on India 
by Nataraj (2011) as well as Goldberg, Khandelwal, Pavcnik, and Topalova (2010a, 2010b), and Topalova and Khandelwal (2011) also shows that tariff reductions on both inputs and final goods are associated with productivity improvements. Topalova and Khandelwal (2011) estimate the impact on listed firms of the reductions in input and output tariffs on total factor productivity (TFP) in India. Like Amiti and Konings, they find that while reducing output tariffs raised TFP, reductions in input tariffs had an even bigger positive impact on measured TFP. Like this recent body of tariff literature, this paper distinguishes between the implications of input and final goods tariffs on FDI spillovers.

The interaction between trade policy and foreign investment flows has long been of research interest to scholars. The classic reference on the interaction between tariffs and FDI is Brecher and Diaz-Alejandro (1977), who formalize the argument proposed by Jagdish Bhagwati (1973) that incoming capital induced by high tariffs can lead to immiserizing growth and a fall in welfare. Foreign capital inflows exacerbate the production and consumption distortions created by tariffs, and by repatriating the profits abroad foreign firms further reduce domestic welfare. Further studies have suggested evidence of "tariff-jumping" FDI, suggesting that foreign firms are attracted to protected domestic markets. While these early studies do not directly speak to the effects of backward spillovers in the presence of tariff distortions, they do suggest that tariffs interact in a harmful way with foreign firms.

We are not aware of any studies which measure the differences in foreign investment spillovers across different levels of corporate tax rates. There are also very few published studies of the impact of trade reforms on firm productivity in China. One exception is $\mathrm{Yu}$ (forthcoming) on the linkages between output tariffs, input tariffs, and processing trade in China. Yu merges the Chinese census data used in this paper with firm-specific measures of final goods 
and imported intermediate input trade to calculate firm-specific final goods and input tariffs. Yu finds that contrary to the results for Indonesia in Amiti and Konings (2007) and Topalova and Khandwal (2011), reductions in final goods tariffs increased productivity more for processing firms than did reductions in intermediate input tariffs. Yu attributes this result in large part to the fact that firms under the processing trade regime were exempted from tariffs on intermediate inputs.

Existing research on the link between tax subsidies and FDI is largely focused on countries and regions apart from China. In their review, Morisett and Pirnia (1999) conclude "incentives will neither make up for serious deficiencies in the investment environment, nor generate the desired externalities." The authors find that, more important than tax preferences, investors are most attentive to "fundamental factors like economic conditions and political climate." Only when such factors are "more or less equal" across locations that offer a similar range of fundamental factors, such as with the U.S. or within the E.U., tax policy may exert a significant impact. While the authors review no studies relating to China, they do find that firms operating in several similar country settings may exploit different tax regimes.

Solis (2011) reviews the literature on developing country subsidies for multinational corporations. He examines the link between subsidized FDI and six critical development factors: competitiveness, social development, democracy, governance, and entrepreneurship and finds no coherent or sustainable justification for FDI subsidies. While Solis does not include any empirical reference to China's experience with FDI, he does suggest that it may differ from that of Latin America with respect to the practice of the Chinese government in imposing greater conditionality on FDI and also having the ability to capture some of the rents from FDI.

Summarizing, we find that FDI may affect firms of different ownership types, depending 
upon the direction of the spillovers and the capacity of the recipient firms to absorb the impact of the spillovers, whether technology, competition, or some combination of the two. While much of the FDI spillover literature focuses on the impacts of FDI on different ownership types in China, we find no prior literature on ways in which tariffs and taxes in China have affected the nature of FDI spillovers in that country.

\section{Basic Framework}

To examine the impact of trade policy and foreign investment promotion, we employ a two stage procedure. In the first stage we estimate a three-input gross-output production function by subsector for firm subsamples representing two ownership types: (1) all firms and (2) domestic firms with zero foreign investment that are not classified as SOEs. We use the estimated factor output elasticities for labor, capital, and materials to construct measures of total factor productivity (TFP) for each firm and year. In the second stage, we regress the dependent variable, lnTFP, on the relevant FDI cluster, policy variables, and controls.

The first-stage production function is:

$\ln Y_{i j t}=\alpha_{0}+\alpha_{L} \ln L_{i j t}+\alpha_{K} \ln K_{i j t}++\alpha_{M} \ln M_{i j t}+\mu_{i j t,}$

where $\mathrm{i}=$ the firm in sector $\mathrm{j}$ and in year $\mathrm{t}=1998-2007$.

For the purpose of estimating the first-stage production function, we employ the Olley-Pakes method to get unbiased estimates of the factor output elasticities. China's Input-Output table divides China's manufacturing industry into 71 sectors (as shown in Table 2). Our firm-level 
survey data include 4-digit level industry classifications. Hence, to construct the intra- and inter-industry spillover variables (as for constructing the input tariff variables), we need to aggregate the 4-digit classifications up to 71 sectors. $^{8}$

When applying with Olley-Pakes estimation procedure, all output and input variables are deflated by their corresponding price indices. We deflate the output value by the 29 individual sector ex-factory price indices of industrial products. ${ }^{9}$ Capital is defined as the net value of fixed assets, which is deflated by a uniform fixed assets investment index, and labor is a physical measure of the total number of employees. Intermediate inputs purchased by firms for the purpose of producing gross output are deflated by the intermediate input price index. ${ }^{10}$

In the second-stage, we regress firm-level TFP on a series of firm-level and sector-level controls, as described in equation (2):

$$
\begin{aligned}
& \text { In } \text { TFP }_{i j t}=\beta_{0}+\beta_{1} \text { ForeignSha reHKTM } \\
& +\beta_{3} \text { StateShare }_{i j t}+\beta_{2} \text { ForeignSha reFizontal }_{j t}+\beta_{5} \text { Backward }_{j t}+\beta_{6} \text { Forward }_{j t}+\beta_{7} \text { Output }_{-} \text {Tariff }_{j t} \\
& +\beta_{8} \text { Input _Tariff }_{j t}+\beta_{9} \text { WTO }+\sum_{i} \alpha_{i}+\sum_{t} \alpha_{t}+\varepsilon_{i j t}
\end{aligned}
$$

In equation (2), $\operatorname{lnTFP} \equiv \ln Y_{i j t}-\left[\alpha_{L} \ln L_{i j t}+\alpha_{K} \ln K_{i j t}++\alpha_{M} \ln M_{i j t}\right]$, where $\alpha_{L,} \alpha_{K}$ and $\alpha_{M}$ are obtained by the OP estimation. The $\alpha_{\mathrm{i}}$ represent firm-level fixed effects and $\alpha_{\mathrm{t}}$ represent annual time dummies. ForeignShareHKTM Fijt $_{\text {, ForeignShareFR }}$, and StateShare $_{i j t}$ are defined as the share of the firm's total equity owned by Hong Kong-Taiwan-Macau investors, foreign investors,

\footnotetext{
${ }^{8}$ For example, the furniture industry (coded as 19 in Table 2) includes 5 four-digit sub-sectors. These are wood furniture manufacturing (2110), bamboo furniture manufacturing (2120), metal furniture manufacturing (2130), plastic furniture manufacturing (2140), and other furniture manufacturing (2190).

9 Sector-specific ex-factory price indices for industrial products appear in China Urban Life and Price Yearbook (2008, Table 4-3-3). The price indices are published for 29 individual sectors, consequently we created a concordance between the 29 and the 71 sectors.

${ }^{10}$ Price indices for fixed investment and industry-wide intermediate inputs are reported in the China Statistical Yearbook (2006) (obtained from the website of the National Bureau of Statistics of China).
} 
and the state respectively. ${ }^{11}$ By construction, these three firm-level controls are continuous variables that range from 0 to 1 in value ${ }^{12}$.

Following Javorcik (2004), we define three sector-level FDI variables. First, Horizontal ${ }_{j t}$ captures the extent of foreign presence in sector $j$ at time $t$ and is defined as foreign equity participation averaged over all firms in the sector, weighted by each firm's share in sectoral output. In other words,

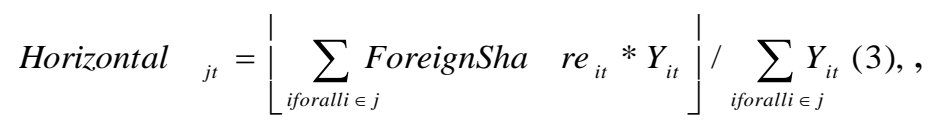

where ForeignSha $r e_{i t}$ is the sum of ForeignSha reHKTM and ForeignSha reFR. Second,

Backward $_{j t}$ captures the foreign presence in the sectors that are supplied by sector $\mathrm{j}^{13}$. Therefore, Backward $_{j t}$ is a measure for foreign participation in the downstream industries of sector $\mathrm{j} . \quad$ It is defined as

$$
\text { Backward }_{j t}=\sum_{k i f k \neq j}^{\prime} \alpha_{j k} \text { Horizontal }{ }_{k t}(4) .
$$

The value of $\alpha_{j k}$ is taken from the 2002 input-output table ${ }^{14}$ representing the proportion of sector j’s production supplied to downstream sector $\mathrm{k}$.

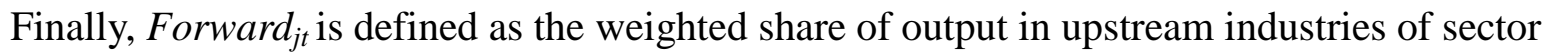
j produced by firms with foreign capital participation. As Javorcik points out, since only

\footnotetext{
11 The omitted share, the non-state domestically-owned share, is represented by the constant term.

12 In some specifications, we run regressions with domestic firms only. For these cases, we use the sample of domestic firms with zero foreign investment. At the individual establishment level, we control for two types of FDI: ForeignShareHKTM and ForeignShareFR $R_{i j t}$. This allows us to determine whether some types of foreign investment are more productive than others. It is generally assumed that OECD-based FDI is more technology-intensive than HKMT FDI. On the other hand, HKMT FDI may be more physically and organizationally integrated with domestic operations than OECD-based FDI. Anecdotal evidence suggests large quantities of so-called foreign investors in China are actually domestic investors who channel investment through Hong Kong in order to take advantage of special treatment for foreign firms (so-called "round tripping"). If this is the case, then we would expect that firms with HKMT ownership might be less productive than other types of FDI.

${ }^{13}$ For instance, both the furniture and apparel industries use leather to produce leather sofas and leather jackets. Suppose the leather processing industry sells $1 / 3$ of its output to furniture producers and $2 / 3$ of its output to jacket producers. If no multinationals produce furniture but half of all jacket production comes from foreign affiliates, the Backward variable will be calculated as follows: $1 / 3 * 0+2 / 3 * 1 / 2=1 / 3$.

${ }^{14}$ Input-output tables of China (2002) Table 4.2, which divides manufacturing industry into 71 sectors.
} 
intermediates sold in the domestic market are relevant to the study, goods produced by foreign affiliates for exports $\left(X_{i t}\right)$ should be excluded. Thus, the following formula is applied:

$$
\text { Forward }_{j t}=\sum_{m i f m \neq j} \delta_{j m}\left\lfloor\left\lfloor\mid \sum_{\text {iforalli } \in m} \text { ForeignSha } r e_{i t} *\left(Y_{i t}-X_{i t}\right)|/| \sum_{i f o r a l l i \in m}\left(Y_{i t}-X_{i t}\right)\right\rfloor\right\rfloor(5) \text {. }
$$

The value of $\delta_{j m}$ is also taken from 2002 input-output table. Since Horizontal $_{j t}$ already captures linkages between firms within a sector, inputs purchased within sector $\mathrm{j}$ are excluded from both Backward $_{j t}$ and Forward $_{j .}$

To test for trade interactions with FDI and control for the effects of trade policies, we have created a time series of tariffs, obtained from the World Integrated Trading Solution (WITS), maintained by the World Bank. We first created a concordance between the tariff data and the Chinese census data at the most disaggregated level possible. ${ }^{15}$ Then, we aggregate up output tariffs to the same industry classification as sectoral FDI, giving us a total of 71 sectors (see Table 2). ${ }^{16}$

We also created a measure of input tariffs. To construct input tariffs, we use China's Input-Ouput table (2002) and follow the procedures suggested by Amiti and Konings (2007). The input tariffs are constructed as a weighted average of the output tariffs. ${ }^{17}$ Finally, we construct a dummy variable, WTO, equal to one after China entered the World Trade Organization at the end of 2001. This is a time dummy equal to zero from 1998 through 2001 and equal to 1 from 2002 onwards. The WTO dummy captures the impact of reforms not captured by tariff measures (such as reductions in non-tariff barriers). The WTO dummy also captures the aggregate

\footnotetext{
15 This was a challenge given that the two series are not in the same nomenclature. For example, we have different categories for ship-building, electronic computers, tobacco products, motor vehicles, and parts and accessories for motor vehicles.

16 To aggregate the tariff line items to the level which would allow us to create a concordance with the census data, we used output for 2003 as weights.

17 The weights are based on input-output table. For instance, if a chocolate producer uses 60 percent sugar and 40 percent cocoa pounder, the input tariff for that chocolate industry is equal to 60 percent of the sugar tariff plus 40 percent of the cocoa tariff. Since China's input-out tables only allow us to calculate input tariffs at the three-digit level, we use the same level of 3-digit disaggregation for final goods tariffs as well.
} 
increase in market access for Chinese firms to export destinations.

\section{Data and Broad Trends}

The dataset employed in this paper was collected by the Chinese National Bureau of

Statistics. The Statistical Bureau conducts an annual survey of industrial plants, which includes manufacturing firms as well as firms that specialize in mining operations and those that produce and supply electricity, gas, and water. The data set is firm-level based, including all state-owned enterprises (SOEs), regardless of size, and non-state-owned firms (non-SOEs) with annual sales of more than 5 million Yuan. We use a ten-year unbalanced panel dataset, from 1998 to 2007. The number of firms per year varies from a low of 162,033 in 1999 to a high of 336,768 in 2007 . The sampling strategy is the same throughout the period; the variation in numbers is driven by changes in ownership or sales volume relative to the threshold. ${ }^{18}$

The dataset contains information on output, fixed assets, total workforce, total wages, intermediate inputs, foreign investment, Hong Kong-Taiwan-Macau investment, sales revenue, and export sales. ${ }^{19}$ We use the criterion of zero foreign ownership to distinguish domestic firms and foreign owned firms, that is, domestic firms are those with zero foreign capital in their total assets. In the dataset, $1,197,597$ observations or 77.5 percent of the observations meet the

\footnotetext{
18 The data show that the 5 million yuan threshold is not a strict rule. Among non-SOEs, about 6 percent of the firms report annual sales of less than 5 million yuan in 1998; this number rises to 8 percent by 1999 and falls after 2003. In 2007, only 1 percent of non-SOEs have annual sales below 5 million yuan.

19 The original dataset over the ten-year period includes 2,226,104 observations and contains identifiers that can be used to track firms over time. Since the study focuses on manufacturing firms, we eliminate non-manufacturing observations. The sample size is further reduced by deleting missing values, as well as observations with negative or zero values for output, number of employees, capital, and the inputs, leaving a sample size of 1,842,786. Due to incompleteness of information on official output price indices, which are reported annually in the official publication, three sectors are dropped from the sample. They are the following sectors: processing food from agricultural products; printing, reproduction of recording media; and general purpose machinery. Thus, our final regression sample size is 1,545,626.
} 
criterion of domestic firms; 22.5 percent are designated as foreign firms. ${ }^{20}$

Table 1 reports the summary statistics for the main variables used in the regressions. The summary statistics report the mean of the ratios, which is different than weighted means that would give more weight to larger firms. The first three columns report means for levels and the last three columns report means for growth rates of the key variables used in the analysis.

The statistical means highlight the remarkable growth rates exhibited by the manufacturing sector during this period, with average real output growing 13.5 percent a year, and the net capital stock growing 10.7 percent per year. Labor input grew significantly slower, with average annual increases of only 1.3 percent per year. Total factor productivity (TFP), which is calculated using the Olley-Pakes two step approach described in more detail in the next section, grew on average 5.6 percent per year, implying a forty percent contribution to overall growth. The means also document that, on average, foreign-invested assets have been almost evenly split between sources in Hong Kong, Taiwan, and Macau ("HKTM"), and foreign investment originating in other locations. The first three columns indicate that the state continues to play an important role in manufacturing, with a mean asset share of 8.9 percent during the sample period; over the sample period the total share of total foreign investment in manufacturing is significantly larger, at 16.8 percent. For the sample as a whole, the average state share during this period fell by approximately 0.7 percentage point per year.

The summary statistics for final goods and input tariffs appear in Tables 1 and 2. During the sample period, average tariffs fell for final goods and input tariffs by 87 and 36 percent

\footnotetext{
20 Actually, the international criterion used to distinguish domestic and foreign-invested firms is $10 \%$, that is, the share of subscribed capital owned by foreign investors is equal to or less than $10 \%$. In an earlier version of the paper, we tested whether the results are sensitive to using zero, $10 \%$, and $25 \%$ foreign ownership. Our results show that between the zero and $10 \%$ thresholds, the magnitude and the significance levels of the estimated coefficients remain close, which makes us comfortable using the more restrictive sample of domestic firms for which the foreign capital share is zero. The results based on the $25 \%$ criterion exhibit small differences, but the results are generally robust to the choice of definition for foreign versus domestic ownership.
} 
respectively, significant declines for a ten year period. While the average level of tariffs during this period, which spans the years before and after WTO accession, was nearly 13 percent, as shown in Table 2, this average masks significant heterogeneity across sectors, with a high of 41 percent in grain mill products and a low of 4 percent in railroad equipment.

One issue which arises is the question of the endogeneity of the tariff changes in the data. Goldberg and Pavcnik (2007) argue that in the case of India's trade reforms that began in earnest in 1991, the largest tariff cuts were in those sectors where tariffs were initially high, in order to comply with WTO entry provisions. Thus, in the case of India, tariff reductions followed from initial tariff levels, a condition that helps to address the fear that tariff changes could be endogeneous with respect to productivity changes at the firm level. We see a similar pattern of tariff reductions in the Chinese case. The scatter plot shown in Figure 4 demonstrates that tariff reductions were highest in those sectors where tariff levels were high at the beginning of the sample period. Thus the reductions were broadly rule-based rather than specific to industry characteristics. In addition, tariffs are defined at the 2 digit level; since tariff categories are quite broad (see Table 2), it is difficult to argue that they are set endogeneously with respect to disaggregated firm level behavior.

In Tables 3-1 and 3-2, we provide summary statistics for the FDI spillover variables in relation to the government's assignment of tax holidays. Table 3-1 reports annual figures for means of the output shares calculated separately for clusters of FDI that do and do not receive corporate income subsidies. In the left panel of Table 3-1, we define our sector-level foreign output shares for only those foreign firms that paid less than the statutory tax rate. In the right panel of Table 3-1, we include sector-level output shares for foreign-invested firms that paid the full rate. The trends show a steady increase in the share of subsidized foreign investment 
between 1998 and 2007. In 1998, at the beginning of the sample period, subsidized FDI accounted for less than to 8 percent of sectoral output, while foreign firms without any sort of tax holidays accounted for nearly 12 percent of sectoral output. By the end of the sample period, while the share of output represented by foreign-invested firms with no tax holidays remained virtually unchanged, the output share represented by foreign investors receiving some form of tax holiday had grown to nearly 14 percent.

Figure 3 shows the distribution of income taxes on profits paid by different types of enterprises for the year 2004. We calculated these effective tax rates using reported income taxes paid as a share of profits, as reported in our dataset. The top left-hand side quadrant shows that a large share of domestically-owned firms, both SOEs and non-SOEs, paid the 33 percent tax rate. In principle, foreign firms received a 15 percent tax subsidy. As shown in Figure 3, only a small minority of foreign-invested firms paid the statutory rate, as indicated by the bottom right-hand side quadrant. In 2004, seven percent of foreign-invested firms paid the statutory rate, compared to almost 40 percent for domestically-owned enterprises; a considerable proportion of the foreign-invested firms appear to have paid corporate tax rates of 20 percent or more.

Table 3-2 reports the percentage of firms that reported subsidies on their valued added taxes, which are reported separately from income taxes on profits. We were also able to calculate actual effective tax rates for value added, since firms separately reported value added taxes paid as well as value-added. Relative to the proportion of firms receiving subsidies on their income taxes, fewer firms receive subsidies in the form of exemptions on value-added taxes. These exemptions increased until 2003, then declined. It is clear from these tables that income tax holidays were a more pervasive form of incentives until the 2008 tax reform. 


\section{Estimation Strategy and Results}

Below, we describe our estimation strategy, the baseline estimation results based on Equation (1), and several variations on that basic regression model for the purpose of examining various interaction effects among the industrial policies under study. Our estimation strategy also tests for the implications of firm heterogeneity within our sample. We also describe our robustness checks.

A. Estimation strategy. We first compute estimates of total factor productivity (TFP) for each firm and each year observation. We divide the sample into two ownership sub-samples. These are (a) all firms and (b) domestic, private firms, which exclude foreign owned enterprises and SOEs. These subsamples and the relevant estimation results are shown in Table A-1.

The earlier literature on the estimation of production functions shows that the use of OLS may be inappropriate, since this method treats labor, capital and other input variables as exogenous. As Griliches and Mairesse (1995) argue, factor inputs should be considered endogenous, since their choice is affected by the firm's productivity. Firm-level fixed effects alone will not solve the problem, because time-varying productivity shocks can affect a firm's input decisions. Using OLS can therefore bias estimates of the relevant coefficients. To solve the simultaneity problem, we employ the procedure suggested by Olley and Pakes (1996) (henceforth OP), which uses investment as a proxy for unobserved productivity shocks.

Table A-1 reports comparisons of the coefficient estimates using the OP approach. As a robustness check, we also employ the procedure suggested by Levinsohn and Petrin (2003) (henceforth LP), which uses intermediate inputs as a proxy for unobserved productivity shocks. Applying these two-stage procedures, both OP (1996) and LP (2003), one would anticipate that 
the coefficient on labor and intermediate inputs should decrease relative to the OLS fixed effects estimator, while the coefficient on capital should increase. To save on space we only report the results using the OP, not the LP procedure or OLS with firm fixed effects. The results are qualitatively similar using both the OP and LP approaches, but LP suffers from the fact that the efficiency of material input use is ignored. The results are generally consistent with these predictions across ownership classes. Relative to OLS with firm fixed effects the coefficient on capital inputs is higher using OP across all specifications. We also generally find that the coefficient on the labor shares and material shares are lower with OP compared to OLS.

One notable feature across all specifications is that the labor estimate is relatively small, compared to estimates for other countries, while the coefficient for material inputs is rather high. As a robustness check, we performed a test in which we use various variables within our data set to compute labor's factor income share. Although the estimation procedure shown in Table A-1 does not impose these restrictive conditions of perfect competition with constant returns to scale, the coefficients on the factor inputs in our estimating equations sum to 0.904 , close to constant returns to scale. Hence, the factor income shares computed from the data in our data set should be similarly comparable to the factor output elasticities shown in Table A1. Using the data for the full sample, we compute an average factor income share for 1998-2007 as equal to 0.105. While this is somewhat larger than 0.086 , the OP estimate reported in Table A-1, the difference is small. Moreover, if our estimate of TFP deviates from the true TFP level by a constant time-invariant scalar, the fixed effects procedure that we use in the second stage should wash out the difference. ${ }^{21}$

B. Baseline results. The baseline results are presented in Table 4. In all the results

\footnotetext{
$21 \quad$ Moreover, if our estimate of TFP deviates from the true TFP level by a constant time-invariant scalar, the fixed effects procedure that we use in the second stage should wash out the difference.
} 
which follow, we separate firms into foreign-invested firms - those with some positive foreign ownership — and domestically-owned firms — defined as enterprises with zero foreign ownership. We first examine the impact of horizontal and vertical FDI spillovers.

FDI spillover estimates. The results for "All firms" are shown in column (1) of Table 4; those for foreign invested firms appear in column (2), and those for domestically-owned firms are shown in column (3). For the samples including all firms (column 1) and domestic firms only (column 3), the coefficients on the state's share in equity are negative and statistically significant, indicating that increases in state-invested shares are associated with lower productivity. We discuss the different effects of spillovers across more detailed ownership categories in subsection $\mathrm{C}$ below. The results for the state share are consistent with the expectation of rising productivity for privatizing enterprises.

Table 4 shows a divergent pattern of results for horizontal and vertical FDI spillovers. Backward spillovers are largest in magnitude across all three samples. Seemingly, with higher proportions of FDI firms downstream, both foreign-invested and domestic upstream suppliers need to be more productive to prosper as suppliers. Our estimated coefficient on backward linkages implies that a one percentage point increase in backward FDI is associated with a 0.8 to 1.1 percentage point increase in TFP. These magnitudes are twice as large as those found by Blalock and Gertler (2008) for Indonesia but smaller than Javorcik's (2004) findings for Lithuania. The results are also somewhat smaller than the robust backward spillover estimates reported by Lin et al (2009), although their paper does not break out the sample by foreign and domestic firms.

For horizontal, intra-industry spillovers, our results show robust results for foreign firms but not for domestic firms. Presumably domestic firms, at lower levels on the technology frontier, 
are less able to capture productivity enhancing impacts from foreign firms within the same industry. By comparison, the forward spillovers show that domestic firms that are downstream from FDI suppliers appear to benefit more than their foreign counterparts. This finding suggests that domestic-owned firms are more likely to purchase and benefit from upstream inputs supplied by foreign firms than other foreign firms.

The impact of tariff protection/liberalization. The coefficients on both the final goods tariffs and input tariffs in Table 4 are positive but not statistically significant. There are several reasons why the negative impact of input or final goods tariffs on productivity may be attenuated in China. A large fraction of firms, particularly exporters, are granted exemptions from paying tariffs; without additional information on which firms pay input tariffs, it is difficult to identify the negative effect of tariffs on inputs for individual firms. Second, tariffs may be imposed for a number of reasons. If tariffs are successfully imposed in sectors where there are externalities in production, then the average effect of tariffs may reflect both (beneficial) targeting and (harmful) disincentives associated with x-inefficiency.

Third, to the extent that Melitz (2003) is correct, many of the productivity gains associated with trade reform may occur through reallocating production towards more efficient firms, rather than within-firm productivity increases associated with greater exposure to international competition. The framework for this paper explicitly measures only the within firm impact of productivity changes associated with tariff reforms, not the cross-firm reallocation that could occur as the least efficient firms exit and the more efficient firms acquire greater market share. Nevertheless, recent estimates for both India and China suggest that during this sample period, as much as 95 percent of productivity increases in manufacturing were due to within firm productivity increases, not reallocation towards more productive firms (Harrison, Martin, and 
Nataraj (2013), Aghion et al (2014)). This suggests that reallocation of production is not the driving force behind productivity growth in China.

In contrast to the insignificant effects of tariff changes on within-firm productivity changes, the coefficient on the WTO dummy is positive and significant across all subsamples, but is much smaller for foreign invested enterprises (FIEs). The positive and significant point estimates suggest that China's entry into the WTO at the end of 2001 was accompanied by a very large increase in within-firm productivity. These large and significant effects of WTO entry stand in contrast to the insignificant and positive tariff effects. Taken together, these results suggest that market access for Chinese exporters and overall changes in the post-WTO membership period led to enormous productivity gains, even if internal tariff reforms by themselves did not.

Table 4 and this section yield several robust findings. These are the pattern of backward FDI spillovers controlling for tariffs across ownership types, the differential impacts of horizontal spillovers appearing to benefit FIEs and SOEs only, and forward spillovers advantaging all enterprises. In addition, we find evidence that the tariffs on final goods and inputs had no significant impact, but that WTO entry led to a large and significant increase in performance across all firms. From this baseline, we now explore different policy and ownership interactions to enhance the gains from FDI spillovers.

\section{The Role of Ownership and FDI Spillovers}

In Table 4, we saw that the coefficient on the state's share in equity is generally negative and statistically significant, indicating that higher levels of state-invested shares are associated with lower levels of productivity. The coefficient estimate, which was -0.017 in column (1) of 
Table 4, suggests that after controlling for other factors, moving from 100 percent SOE to 100 percent private would be associated with a productivity gain of nearly two percentage points. Now we will explore how other factors, including FDI spillovers and trade policy, vary by ownership type.

In Table 5, we divide the samples of foreign-invested and domestic firms into two groups, SOEs and non-SOEs, to test whether the formal ownership structure and the composition of asset ownership matter for FDI spillover effects and trade policies. As in Table 4, all of the regressions are estimated with firm-level fixed effects and year effects, and robust standard errors are clustered at the sector level. The results in columns (1) and (2) include all SOEs and all non-SOEs, with and without foreign-equity participation. Columns (3) and (4) show the results using the sample of foreign-invested firms, and columns (5) and (6) present the results using the sample of the domestically-owned firms with zero foreign equity participation.

The first two columns allow us to compare the impact of firm-level equity participation by foreign investors on the productivity of SOEs relative to non-SOEs. The coefficient on foreign participation from foreign investors outside of Greater China (HKMT) for SOEs is 0.007 and significant relative to 0.05 and not significant for non-SOEs. This result suggests that foreign equity participation is associated with an improvement in productivity which is greater for SOEs. The larger and statistically significant coefficient associated with foreign equity participation in SOEs is consistent with the hypothesis that firms with foreign equity have played an important role in improving SOE performance.

Comparing FDI spillover impacts on SOEs and non-SOEs, forward spillovers are significant and robust for all types of enterprises. As shown in the fourth column, SOEs with some foreign-investment appear to be most effective at capturing productivity benefits from both 
upstream and downstream FDI clusters. Some of this estimated benefit may result from flows of capital and technology from downstream FDI users to their upstream SOE suppliers and from upstream FDI suppliers to their downstream SOE buyers.

With respect to horizontal spillovers, among the six estimates, we only see evidence of significant spillovers to other FIEs or to SOEs. Among the population of firms in our sample, this set of firms may best exhibit the combination of a significant technology gap and capacity to absorb the relevant technologies to narrow the gap. Private or non FIE invested enterprises may not exhibit a substantial gap with foreign invested firms or they may not have the absorptive capacity to effectively capture these proximate intra-industry technologies. This result is broadly consistent with the findings of the three papers reviewed in our literature review, which find negligible, or negative, intra-industry FDI spillover impacts.

Concerning the matter of tariffs and trade liberalization, Table 5 shows significantly different responses to tariffs across SOEs and non-SOEs. Relative to non-SOEs, in the face of higher final goods tariffs, SOEs exhibit significantly lower productivity, particularly in the foreign-invested sector. The point estimates on final goods tariffs, which are -0.076 for SOEs with foreign investment and -0.052 for those with no foreign assets, suggests that a one percent reduction in tariffs (ceteris paribus) would increase productivity by 0.076 to 0.052 percent respectively. The relative responsiveness of productivity to tariff reduction in the state sector suggests that the persistence of tariff protection for SOEs may have created or sustained more inefficiency in the state enterprises that could not be sustained in the face of increased final goods competition.

In Table 5, we also distinguish between the effects of WTO entry across ownership types. While WTO entry was associated with significant increases in productivity across all ownership 
types, important differences emerge. The benefits from WTO entry were smallest for foreign invested enterprises, which is consistent with those firms being closest to the technology frontier and benefiting least from increasing market access and global competition. In constrast, the benefits were greatest for domestic enterprises. The coefficient for domestic, non-SOEs was 0.315, compared to 0.026 for FIEs without state ownership. This suggests that gains from WTO entry were 15 times larger for domestic relative to foreign enterprises.

The F-tests listed at the bottom of the Table 5 identify whether vertical and horizontal spillovers from FDI were significantly different across SOEs and non-SOEs. Across all subsets of enterprises, spillover differences from FDI exhibit a markedly different pattern for SOEs relative to private enterprises. Backward spillovers were three times as large for SOEs with foreign partners relative to private firms with foreign partners. Forward spillovers were also significantly larger for SOEs with foreign partners relative to non-SOEs. However, for SOEs without foreign partners, spillovers were significantly smaller than for other domestic enterprises. The results suggest that the benefits to SOEs from foreign externalities were largest when those SOEs also had foreign partners. Due to these ownership differences, in the rest of the paper we further differentiate categories of ownership by reporting the separate effects of horizontal and vertical spillovers for SOEs, private, and joint venture enterprises.

D. Trade Policy Changes and FDI Spillovers. While there is a large literature which investigates the impact of FDI on productivity, as well as an even larger literature that explores the relationship between trade policies and productivity (for an overview of both these topics, see Harrison and Rodriguez-Clare (2010)), we are not aware of any study that examines how changing levels of protection affect the magnitude of FDI spillovers. In this section, we explore 
how FDI spillovers changed with a discrete change in trade policy: China's entry into the WTO.

Specifically, we explore changes in FDI spillover impacts before and after China's

ascension to the WTO in 2001. We know that China's 2001 WTO ascension led to a substantial decline in tariffs. Table 2, for example, shows that for over 71 industry categories, during 1998 to 2007, China's average manufacturing final goods tariff was 12.7 percent. By 2007, the average final goods tariff in that year had declined by 8.9 percent to just 30 percent of the average for the sample period. Our question, therefore, is whether this across the board reduction in tariffs during 1998-2007 affected the magnitude or direction of China's FDI spillovers.

We explore how trade policy changes affected FDI spillovers through two different specifications. First, in Table 6A, we add an interaction term for WTO entry and FDI at the vertical and horizontal level. This means that we add three interaction terms: Horizontal*WTO, Backward*WTO, and Forward*WTO. In Table 6B, we instead interact our FDI measures with tariffs. To the extent that trade policy affects the magnitude of FDI spillovers, we would expect the interactions to be significant. If greater trade liberalization positively affects spillovers, we would expect the interactions with the WTO dummy variable to be positive and the interactions with tariffs to be negative.

In Table 6A, we explore how vertical and horizontal linkages varied before and after China's WTO entry at the end of 2001. With China's entry into the WTO in the middle of the sample period, domestic content rules became illegal and tariffs were significantly reduced. The results in Table 6A indicate that vertical backward linkages were strengthened during the second half of the sample period, when tariffs were lowered and domestic content restrictions relaxed. Among the three spillover directions, the most dramatic change is the set of backward 
spillover estimates for which the number of robust estimates rises. The interaction between Backward FDI and WTO is significant for all subsamples except for SOEs partnering with foreign enterprises. The coefficient estimates suggest that backward linkages shifted from negative to large, positive and significant post-WTO entry.

Table 6B confirms the findings from Table 6A, using actual tariff levels instead of the WTO dummy to measure the interaction with sectoral FDI linkages. Once we take into account the possible interaction with tariffs, we find large, significant, and positive effects of backward linkages across all types of enterprises. Horizontal linkages generally become small in magnitude and insignificant across all types of enterprises. Forward linkages remain significant for foreign-invested SOEs, but not for other types of firms. The interaction between tariffs and backward linkages is significant and negative, indicating that higher tariffs reduce backward spillovers, across all ownership types.

Hence, the most dramatic impact of China's WTO ascension on FDI spillover outcomes is evident in our backward linkage estimates. As shown in Tables 6A and 6B, the increase in backward spillover impacts is notable for each of the four distinct ownership types we explore: foreign-invested SOEs and non-SOEs and domestic-owned SOEs and non-SOEs. The across-the-board tariff reductions appear not to have affected the efficacy of horizontal and forward linkages. The increase in the robustness of backward linkages is likely to reflect the fact that the combination of tariff reductions and reductions in domestic content restrictions required upsteam suppliers to improve the efficiency and quality of the inputs they supplied to cost and quality-conscious downstream foreign invested firms. With the reduction in barriers to trade, downstream foreign producers could choose to alternatively source from overseas foreign suppliers to substitute for established upstream producers that had benefited from pre-WTO trade 
barriers. The threat of alternative suppliers and the reduction in trade distortions together led to significant increases in backward linkages across all ownership categories of enterprises.

E. The Effects of Tax Incentives on FDI Spillovers. In Tables 7 and 8 we explore the extent to which subsidized foreign investment exerts a differential impact on spillovers relative to unsubsidized foreign investment. While the standard income tax rates across all firms during the sample period 1998-2007 was 33 percent, a large share of foreign-owned firms was granted tax subsidies and faced tax rates that were significantly lower. We are able to calculate the extent of subsidies by calculating for each enterprise their effective tax rate, defined as taxes on corporate profits divided by net profits. The difference between the corporate tax rate and the actual tax rate paid is how we define the extent of the establishment-specific subsidy. Since the data separates out income taxes paid and value-added taxes paid by the enterprise, we are able to separately calculate tax holidays on both income tax and VAT obligations.

The summary statistics reported in Tables 3-1 and 3-2 suggest that the majority of foreign investment in China during the sample period benefited from income tax subsidies and a significant fraction benefited from subsidies on value-added taxes. To the extent that the Chinese government successfully targeted sectors and firms more likely to convey positive externalities, we would expect more robust spillovers effects emanating from the firms and sectors benefitting from subsidies. To test for the possibility of differential spillover effects, we split our sector-level foreign share variables into two groups: one is calculated based on foreign investment being subsidized (those paying less than the statutory tax rate) ${ }^{22}$ and the other series is computed based on non-subsidized foreign investment.

The results, summarized in Table 7, once again show that much of the action centered on

\footnotetext{
22 As discussed earlier, the statutory tax rate in China is $33 \%$. However, foreign-invested firms receive a preferential tax break of $15 \%$. In this paper, we use the cut-off of a $20 \%$ tax rate to distinguish whether a foreign-invested firm is being subsidized.
} 
backward spillovers. For subsidized FDI in downstream industries, our estimated spillovers are both notably large and consistently robust at the one percent level across five out of six ownership types. For unsubsidized FDI, the backward spillovers become insignificant or even negative for all firms except SOEs with foreign investment. The F-tests at the bottom of Table 7 are only significant for subsidized FDI, suggesting that on average, tax holidays did indeed target sectors with greater externalities. By comparison, horizontal spillovers show no notable difference for intra-industry FDI that is subsidized or unsubsidized. The robust forward spillovers for foreign invested firms, whether SOEs or not, persist in about the same degree with and without subsidies to upstream industries.

The results in Table 7 suggest that when subsidized downstream FDI appears to have more impact than unsubsidized FDI. While these results are consistent with smart tax policies, our results cannot at this point be interpreted as causal. What is evident, however, is that foreign-owned buyers of upstream domestic inputs were more likely to generate spillovers when they also received tax holidays. Downstream subsidized FDI may have attracted different kinds of downstream producers than unsubsidized investors. This issue deserves further research. What Table 7 does indicate is that tax holidays to downstream foreign firms were more likely to be associated with positive externalities than tax holidays to upstream foreign firms.

In Table 8, we test whether the results differ when we explore tax holidays on value-added taxes as a form of fiscal incentive rather than the income tax holidays examined above. In Table 8, we redefine subsidized firms on the basis of lower value-added taxes instead of lower corporate income taxes. We define firms as subsidized when they are exempted altogether from paying value-added taxes. Overall, the results in Table 8 are consistent with differences in the effects of foreign investment based on income tax incentives, i.e. the provision of subsidies is 
associated with larger, more robust spillovers. However, the composition of the spillover effects of VAT holidays differs somewhat from reductions in corporate income taxes. Here much of the action focuses on horizontal spillovers. The non-subsidized horizontal FDI seemingly creates fewer or no spillovers; by contrast, the horizontal spillovers associated with firms that enjoy VAT subsidies are consistently large and robust at the one percent level of significance.

The evidence presented in Tables 7 and 8 suggests that across both corporate taxes and VAT obligations, tax holidays were consistently associated with higher externalities from FDI. In the case of corporate tax holidays, most of the differences were in the magnitude of backward linkages. For VAT obligations, most of the differences were in intra-industry spillovers. While we cannot identify the causal linkages, the evidence is consistent with an industrial policy such as China's "technology for market" program, where foreign firms that agreed to make accessible aspects of their technology may have received, in return, corporate income tax holidays or VAT subsidies for their investment and production.

F. Robustness Tests. Since our dependent variable is firm-level productivity and the focus of the analysis is on how sector-level foreign investment affects domestic firm productivity, endogeneity is unlikely to be an issue. To the extent that foreign investment might be attracted to sectors where suppliers or users are more productive, this condition is accounted for by the use of firm-level fixed effects. Furthermore, where foreign investment is drawn to sectors that exhibit either high or low tariffs (or possibly systematically high or low productivity levels), the inclusion of the tariff variable will control for this potential source of omitted variable endogeneity bias. 
However, some might argue that foreign investors are drawn to sectors where they expect higher productivity growth in the future. To address this potential source of endogeneity, we also applied instrumental variables (IV) techniques which are available upon request from the authors. We used future tariffs (tariffs at time $t+1$ ) as instruments. For backward linkages for domestic non-SOEs, the point estimates were magnified, confirming the importance of the linkages between domestic suppliers and foreign-owned buyers of their inputs. However, the coefficients on horizontal linkages became negative across all subsamples, but not statistically significant. The negative coefficient on the horizontal variable is consistent with our evidence suggesting lack of significant intra-industry spillovers to domestic non-SOEs in this paper as well as previous work by Aitken and Harrison (1999) and others suggesting that foreign firms take away market share from domestic competitors in the same industry.

\section{Concluding Comments}

In this paper, we investigate how tax and tariff policies affect FDI spillovers in Chinese industry. Is it possible to enhance the externalities from FDI through trade policies or tax holidays? We find that the answer is yes. We also explore how externalities from FDI, tariffs, and tax holidays vary across China's heterogenous ownership structure. To our knowledge, this is the first study to examine whether targeted subsidies for FDI are associated with stronger linkages from FDI to domestically-owned and/or foreign-invested firms. To identify the interactions between FDI spillovers and trade policies, we examine the role of both tariff reductions and China's entry into the WTO.

By taking into account trade policy changes and interactions between trade and FDI, our 
results indicate significantly higher effects of backward linkages in China. In fact, prior to China's entry into the WTO backward linkages appear to be negative and the very large and significant backward externalities only emerge once we take into account the impact of trade reforms on FDI. The positive impact of backward linkages which emerges post-trade reform is consistent with the early literature on immiserizing FDI, which posited negative effects of FDI in highly protected economies.

Across a variety of specifications, we find that backward and forward linkages increased the productivity of Chinese and joint venture enterprises. Horizontal linkages, however, were generally restricted to FIEs and SOEs. In other words, positive externalities within the same sector were restricted to public enterprises or to other joint ventures. During our sample period, all of these spillover channels, particularly the vertical linkages, were affected by industrial policy associated with tariff reductions and the deployment of corporate income and VAT subsidies.

Exploiting the exogenous change in trade policies with China's entry into the WTO at the end of 2001, we investigate the impact of China's substantial tariff liberalization on the magnitude and direction of FDI productivity spillovers. We do this in two ways. First we interact tariff changes with our measures of sectoral FDI. Second, we interact WTO entry with sectoral FDI. Using both approaches shows that trade liberalization was accompanied by significant increases in FDI linkages, particularly for backward linkages. Since China's entry into the WTO created pressure to phase out domestic content rules (in order to comply with the WTO), we might have expected to find a reduction in backward linkage spillovers. Instead, backward linkages became stronger after WTO entry, possibly because the additional competition forced domestic suppliers to improve their efficiency and quality. The increase in 
vertical linkages from FDI following the reduction in trade distortions is consistent with an earlier academic literature that posited welfare losses from FDI attracted by tariff distortions.

Finally, we explore the spillover implications of tax subsidies that have been targeted to foreign investment within certain sectors and by certain firms. We find strong evidence that subsidized foreign investment generates greater productivity spillovers than unsubsidized investment. The estimates imply that a one percent increase in the share of foreign investment in downstream sectors raises the supplying firm's productivity by 2 to 3 percentage points. Across our sample spanning a ten year period, vertical linkages accounted for an important source of productivity gains for all types of enterprises.

One advantage of incorporating different industrial policy instruments into a single framework is that it allows us to compare the effectiveness of these different approaches on firm productivity. If a central goal of China's industrial policy has been to raise firm productivity, we find that the use of different instruments has had notable positive effects but also some perverse impacts. High tariffs, particularly high final goods tariffs, were associated with depressed productivity for SOEs. FDI spillovers are moderate to robust, with vertical backward and forward spillovers particularly strong. China's entry into the WTO also substantially strengthened the impacts of vertical FDI spillovers. FDI subsidies through the use of tax corporate income subsidies were associated with significantly larger backward FDI linkages; VAT subsidies have most strengthened the positive impact of horizontal spillovers. During the period of our study, 1998-2007, China's industrial policy has generally served to enhance the impacts of these spillovers. 


\section{REFERENCES}

Amiti, M., and Konings, J. (2007), "Trade Liberalization, Intermediate Inputs and Productivity." American Economic Review, 97(5), 1611-1638

Arnold, J., Javorcik, B. and Mattoo, A. (2008), "Do Manufacturing Firms Benefit from Foreign Direct Investment in Services Industries? Evidence from the Czech Republic.” Mimeo.

Aitken, B. J. and Harrison, A.E. (1999), "Do Domestic Firms Benefit from Direct Foreign Investment? Evidence from Venezuela.” American Economic Review, 89 (3), 605-18.

Aitken, B.J., Harrison, A. E., and Lipsey, R.E. (1996), "Wages and Foreign Ownership. A comparative study of Mexico, Venezuela and the United States.” Journal of International Economics, (40), 345-371.

Brandt, L., Van Biesebroeck J., Wang L.H., and Zhang Y.F. (2012), "WTO Accession and Performance of Chinese Manufacturing Firms,” CEPR Discussion Paper, no. 9166.

Brecher, R., and Dias Alejandro, C. (1977), "Tariffs, Foreign Capital and Immiserizing Growth." Journal of International Economics, (7), 317-322.

Blalock, G. and Gertler, P.J. (2008), "Welfare Gains from Foreign Direct Investment through Technology Transfer to Local Suppliers" Journal of International Economics, 74(2), 402-421.

Blomstrom, M., "Foreign Investment and Productive Efficiency: The Case of Mexico." (1986), Journal of Industrial Economics, 1986 (35), 97-110.

Ethier, W. (1982). "National and International Returns to Scale in the Model Theory of International Trade.” American Economic Review, 72, 389-405.

Goldbert, P. K. and Pavcnik , N. (2007), "Distributional Effects of Globalization in Developing Countries," Journal of Economic Literature, 45(1) 39-82.

Griliches, Z. and Jacques M. (1995), "Production Functions: The Search for Identification." National Bureau of Economic Research (Cambridge, MA) Working Paper No. 5067, March 1995.

Haddad, M. and Harrison, A.E. (1993). "Are There Positive Spillovers from Direct Foreign Investment? Evidence from Panel Data for Morocco.” Journal of Development Economics, 42 (1), 51-74.

Harrison, A.E. and Rodriguez-Clare, A. 2010, "Trade, Foreign Investment, and Industrial Policy for Developing Countries," in Handbook of Development Economics, 5, edited by Dani R. and Mark R. pp. 4039-4214.

Hu, A. and Jefferson, G.H. (2002) "FDI Impact and Spillover: Evidence from China's Electronic 
and Textile Industries", World Economy, 25 (8) 1063-76.

Jefferson, G.H. and Ouyang, M. (2014), "FDI Spillovers in China: Why Do the Research Findings Differ So Much?," Journal of Chinese Economic and Business Studies, 12.1: 1-27.

Javorcik, J. B. (2004). "Does Foreign Direct Investment Increase the Productivity of Domestic Firms? In Search of Spillovers through Backward Linkages," American Economic Review, 94 (3), 605-627.

Lin, P., Liu, Z.M., Zhang, Y.F. (2009), "Do Chinese Domestic Firms Benefit from FDI Inflow? Evidence of Horizontal and Vertical Spillovers"' China Economic Review, 20, pp. 677-691.

Khandelwal, A. and Topalova P. (2011), "Trade Liberalization and Firm Productivity: the Case of India", The Review of Economics and Statistics, 93(3): 995-1009.

Kokko, A. (1999), “Technology, Market Characteristics and Spillovers.” Journal of Development Economics, 43, 279-93.

Levinsohn J., and Petrin, A. (2003), "Estimating Production Functions Using Inputs to Control for Unobservables." Review of Economic Studies, 70), 317-41.

Lin, P., Liu, Z.M, and Zhang Y.F. (2009), "Do Chinese domestic firms benefit from FDI inflow? Evidence of horizontal and vertical spillovers?" China Economic Review, 20, 677-691.

Morisset, J. and Pirnia, N. (1999), "How Tax Policy and Incentives Affect Foreign Direct Investment," World Bank, Policy Research Working Paper, published November 1999.

Moulton, B. R. (1990), "An Illustration of a Pitfall in Estimating the Effects of Aggregate Variables on Micro Units." Review of Economics and Statistics, 72 (2), pp. 334-38.

Nataraj, S. (2011). "The Impact of Trade Liberalization on Productivity: Evidence from India's Formal and Informal Manufacturing Sectors," Journal of International Economics, 85, 292-301.

Naughton, B. (1996), "China's Emergence and Prospects as a Trading Nation", Brookings Papers on Economic Activity 27(2), 273-304.

Naughton, B. (2007). The Chinese Economy: Transition and Growth, MIT Press.

Solis, Otton, (2011) "Subsidizing Multinational Corporations: Is That a Development Policy?" Kellogg Institute, Working Paper \#381, November 2011.

Trefler, D. (2004). "The Long and Short of the Canada-U.S. Free Trade Agreement", The American Economic Review, 94 (4), 870-895.

Yu, M.L. (forthcoming), "Processing Trade, Tariff Reductions, and Firm Productivity: Evidence from Chinese Products", Economic Journal. 
Table 1. Summary Statistics for All Years, 1998-2007

\begin{tabular}{|c|c|c|c|c|c|c|}
\hline & \multicolumn{3}{|l|}{ Levels } & \multicolumn{3}{|l|}{ Growth Rates } \\
\hline & $\begin{array}{l}\text { Number of } \\
\text { observations }\end{array}$ & Mean & Std. Dev. & $\begin{array}{c}\text { Number of } \\
\text { observations }\end{array}$ & Mean & Std. Dev. \\
\hline $\log Y$ & $1,545,626$ & 10.015 & 1.343 & $1,086,616$ & 0.135 & 0.563 \\
\hline $\log L$ & $1,545,626$ & 4.808 & 1.152 & $1,086,616$ & 0.013 & 0.503 \\
\hline $\log \mathrm{K}$ & $1,545,626$ & 8.468 & 1.719 & $1,086,616$ & 0.107 & 0.753 \\
\hline $\ln$ TFP & $1,545,626$ & 1.828 & 0.367 & $1,086,616$ & 0.056 & 0.308 \\
\hline $\begin{array}{l}\text { Foreign share (contributed by } \\
\text { HK-Taiwan-Macau } \\
\text { investors) }\end{array}$ & $1,545,626$ & 0.089 & 0.267 & $1,086,616$ & 0.012 & 0.377 \\
\hline $\begin{array}{l}\text { Foreign share (contributed by } \\
\text { other investors) }\end{array}$ & $1,545,626$ & 0.079 & 0.249 & $1,086,616$ & 0.000 & 0.146 \\
\hline Stateshare & $1,545,626$ & 0.089 & 0.272 & $1,086,616$ & -0.007 & 0.147 \\
\hline Horizontal FDI & $1,545,626$ & 0.254 & 0.142 & $1,086,616$ & 0.004 & 0.046 \\
\hline Backward FDI & $1,545,626$ & 0.077 & 0.046 & $1,086,616$ & 0.002 & 0.015 \\
\hline Forward FDI & $1,545,626$ & 0.103 & 0.173 & $1,086,616$ & 0.004 & 0.066 \\
\hline Tariff on final goods & $1,545,626$ & 12.691 & 6.600 & $1,086,616$ & -0.869 & 2.295 \\
\hline Tariffs on inputs & $1,545,626$ & 9.185 & 4.064 & $1,086,616$ & -0.359 & 2.066 \\
\hline
\end{tabular}

Notes: We define firm-level foreign share according to its different sources. Foreign share contributed by HK-Taiwan-Macau is defined as the share of firms' total equity owned by investors from

HK-Taiwan-Macau. Foreign share contributed by other countries is defined as the share of firms' total equity owned by investors outside HK-Taiwan-Macau, principally from OECD countries. State share is defined as the proportion of the firm's state assets to its total equity. Horizontal captures the intra-industry FDI spillover while backward and forward represent inter-industry FDI spillovers. We define horizontal, backward, and forward in equation (2), (3), and (4) respectively. The unit for the tariff variable is percentage. 


\begin{tabular}{|c|c|c|c|}
\hline \multirow[b]{3}{*}{ Industry names } & \multicolumn{2}{|c|}{ Final Goods Tariff } & \multirow[t]{2}{*}{ Input Tariffs } \\
\hline & & Difference Between & \\
\hline & Mean & 1998 and 2007 & Mean \\
\hline 1.Grain mill products & 41.002 & -18.290 & 19.799 \\
\hline 2.Forage & 13.501 & -7.871 & 1.932 \\
\hline 3.Vegetable oil refining & 19.852 & -21.772 & 8.796 \\
\hline 4.Sugar manufacturing & 37.101 & 10.710 & 14.656 \\
\hline 5.Slaughtering and meat processing & 18.949 & -4.510 & 15.193 \\
\hline 6.Fish and fish products & 16.052 & -12.419 & 10.698 \\
\hline 7.All other food manufacturing & 22.206 & -13.238 & 12.642 \\
\hline 8.Wines, spirits and liquors & 27.569 & -34.290 & 4.384 \\
\hline 9. Soft drink and other beverages & 28.916 & -20.560 & 1.328 \\
\hline 10.Tobacco products & 49.584 & -24.000 & \\
\hline 11.Cotton textiles & 14.963 & -13.881 & 14.558 \\
\hline 12.Woolen textiles & 14.963 & -13.881 & 11.505 \\
\hline 13.Hemp textiles & 14.961 & -13.884 & 8.632 \\
\hline 14.Textiles products & 17.674 & -15.005 & 12.958 \\
\hline $\begin{array}{l}\text { 15.Knitted and crocheted fabrics and } \\
\text { articles }\end{array}$ & 20.082 & -17.936 & 13.452 \\
\hline 16.Wearing apparel & 21.997 & -16.212 & 11.568 \\
\hline 17.Leather, fur, down and related products & 19.176 & -8.271 & 3.691 \\
\hline $\begin{array}{l}\text { 18.Products of wood, bamboo, cane, palm, } \\
\text { straw }\end{array}$ & 8.849 & -8.346 & 8.130 \\
\hline 19.Furniture & 11.701 & -18.51 & 12.740 \\
\hline 20.Paper and paper products & 11.975 & -12.734 & 13.265 \\
\hline $\begin{array}{l}\text { 21.Printing, reproduction of recording } \\
\text { media }\end{array}$ & 13.584 & -14.950 & 15.092 \\
\hline 22.Stationary and related products & 18.112 & -5.306 & 9.624 \\
\hline $\begin{array}{l}\text { 23. Toys, sporting and athletic and } \\
\text { recreation products }\end{array}$ & 12.120 & -14.198 & 1.494 \\
\hline 24.Petroleum and nuclear processing & 6.499 & -0.930 & 11.159 \\
\hline 25.Coking & 5.479 & -0.080 & 7.447 \\
\hline 26. Basic chemicals & 6.848 & -3.131 & 10.513 \\
\hline 27.Chemical fertilizers & 7.511 & 3.152 & 2.418 \\
\hline 28.Chemical pesticides & 8.974 & -2.071 & 1.169 \\
\hline $\begin{array}{l}\text { 29.Paints, varnishes and similar coatings, } \\
\text { printing ink }\end{array}$ & 9.242 & -3.710 & 10.096 \\
\hline 30.Man-made chemical products & 10.043 & -6.108 & 11.981 \\
\hline 31.Special chemical products & 12.661 & -5.804 & 10.784 \\
\hline 32.Chemical products for daily use & 16.088 & -11.882 & 7.675 \\
\hline 33.Medical and pharmaceutical products & 6.535 & -4.599 & 1.817 \\
\hline 34.Chemical fibers & 9.825 & -12.423 & 11.829 \\
\hline 35.Rubber products & 16.167 & -3.752 & 12.782 \\
\hline 36.Plastic products & 12.583 & -8.299 & 12.860 \\
\hline 37.Cement, lime and plaster & 11.811 & -2.741 & 9.913 \\
\hline
\end{tabular}


38. Glass and glass products

39.Pottery, china and earthenware

15.457

18.236

$-4.890$

10.669

40.Fireproof materials

9.777

$-12.031$

6.928

41.Other nonmetallic mineral products

10.030

$-3.671$

7.751

42.Iron-smelting

6.601

$-2.355$

8.187

43.Steel-smelting

$-3.760$

7.720

6.601

$-3.760$

9.424

44.Steel pressing

6.601

$-3.760$

11.368

45.Alloy iron smelting

6.601

$-3.760$

6.282

46.Nonferrous metal smelting

6.189

$-2.382$

7.897

47.Nonferrous metal pressing

5.630

$-2.331$

11.921

12.788

$-4.814$

12.599

49.Boiler, engines and turbine

10.081

$-4.635$

10.693

50.Metalworking machinery

10.978

$-5.201$

8.637

51.Other general industrial machinery

10.869

$-6.203$

11.131

52.Agriculture, forestry, animal husbandry

8.253

$-5.070$

1.163

53. Other special industrial equipment

9.871

$-5.426$

9.798

54.Railroad transport equipment

4.082

55.Motor vehicles

29.126

$-1.340$

2.403

7.771

17.584

$-26.921$

13.769

and their engines

7.365

$-18.570$

2.488

25.944

$-1.151$

3.349

58. Other transport equipment

10.725

$-9.094$

9.195

60.Household electric appliances

18.441

$-6.465$

7.640

61.Other electric machinery and equipment

15.103

$-7.963$

12.144

10.992

$-5.202$

4.279

63.Electronic computer

$-13.480$

5.235

64. Other computer peripheral equipment

8.422

$-14.87$

7.261

65.Electronic element and device

8.352

$-14.828$

10.988

66. Radio, television and communication

equipment and apparatus

4.912

$-7.010$

5.635

67.Other electronic and communication

equipment

21.374

$-13.97$

5.169

68.Instruments, meters and other measuring

9.528

$-5.450$

8.603

69.Cultural and office equipment

10.097

$-5.150$

4.231

10.460

$-9.548$

6.483

19.324

$-7.374$

9.855

71.Other manufacturing products

12.691

$-5.036$

9.185 
Table 3-1. Summary Statistics for Subsidized and non-Subsidized Spillover Variables (calculated based on income tax)

\begin{tabular}{|c|c|c|c|c|c|c|c|c|c|c|c|c|c|}
\hline \multirow[b]{3}{*}{ Year } & \multirow[b]{3}{*}{$\begin{array}{l}\text { Number of } \\
\text { Observa- } \\
\text { Tions }\end{array}$} & \multicolumn{6}{|c|}{ Subsidized } & \multicolumn{6}{|c|}{ Non-subsidized } \\
\hline & & \multicolumn{2}{|c|}{ Horizontal } & \multicolumn{2}{|c|}{ Backward } & \multicolumn{2}{|c|}{ Forward } & \multicolumn{2}{|c|}{ Horizontal } & \multicolumn{2}{|c|}{ Backward } & \multicolumn{2}{|c|}{ Forward } \\
\hline & & Mean & Std. Dev. & Mean & Std. Dev. & Mean & Std. Dev. & Mean & Std. Dev. & Mean & $\begin{array}{l}\text { Std. } \\
\text { Dev. }\end{array}$ & Mean & $\begin{array}{l}\text { Std. } \\
\text { Dev. }\end{array}$ \\
\hline 1998 & 95,879 & 0.076 & 0.060 & 0.022 & 0.015 & 0.024 & 0.047 & 0.112 & 0.068 & 0.033 & 0.018 & 0.038 & 0.050 \\
\hline 1999 & 103,945 & 0.083 & 0.067 & 0.025 & 0.018 & 0.027 & 0.056 & 0.125 & 0.069 & 0.040 & 0.020 & 0.046 & 0.064 \\
\hline 2000 & 102,465 & 0.096 & 0.072 & 0.029 & 0.020 & 0.033 & 0.070 & 0.130 & 0.070 & 0.041 & 0.021 & 0.049 & 0.068 \\
\hline 2001 & 114,461 & 0.102 & 0.075 & 0.031 & 0.020 & 0.034 & 0.057 & 0.130 & 0.067 & 0.039 & 0.021 & 0.052 & 0.083 \\
\hline 2002 & 122,218 & 0.107 & 0.080 & 0.035 & 0.025 & 0.041 & 0.091 & 0.128 & 0.066 & 0.037 & 0.018 & 0.047 & 0.059 \\
\hline 2003 & 138,158 & 0.110 & 0.078 & 0.034 & 0.023 & 0.042 & 0.083 & 0.131 & 0.069 & 0.039 & 0.021 & 0.053 & 0.080 \\
\hline 2004 & 202,551 & 0.132 & 0.090 & 0.041 & 0.027 & 0.054 & 0.110 & 0.129 & 0.063 & 0.038 & 0.020 & 0.051 & 0.070 \\
\hline 2005 & 194,120 & 0.132 & 0.096 & 0.041 & 0.028 & 0.055 & 0.110 & 0.131 & 0.064 & 0.039 & 0.021 & 0.058 & 0.092 \\
\hline 2006 & 216,924 & 0.138 & 0.094 & 0.043 & 0.028 & 0.057 & 0.101 & 0.126 & 0.061 & 0.039 & 0.020 & 0.057 & 0.097 \\
\hline 2007 & 254,905 & 0.138 & 0.089 & 0.044 & 0.026 & 0.062 & 0.111 & 0.119 & 0.061 & 0.036 & 0.021 & 0.054 & 0.086 \\
\hline
\end{tabular}

Notes: Table 3-1 reports trends in subsidized and non-subsidized foreign investment. In the left panel of Table 3-1, we redefine our sector-level foreign share variables by restricting them to only those foreign firms who paid less than the statutory tax rate. In the right panel of Table 3-1, we redefine sector-level foreign share to restrict it to those firms who paid the full rate. 
Table 3-2. Summary Statistics for Subsidized and non-Subsidized Spillover Variables (calculated based on value added tax)

\begin{tabular}{|c|c|c|c|c|c|c|c|c|c|c|c|c|c|}
\hline \multirow[b]{3}{*}{ Year } & \multirow[b]{3}{*}{$\begin{array}{l}\text { Number of } \\
\text { Observations }\end{array}$} & \multicolumn{6}{|c|}{ Subsidized } & \multicolumn{6}{|c|}{ Non-Subsidized } \\
\hline & & \multicolumn{2}{|c|}{ Horizontal } & \multicolumn{2}{|c|}{ Backward } & \multicolumn{2}{|c|}{ Forward } & \multicolumn{2}{|c|}{ Horizontal } & \multicolumn{2}{|c|}{ Backward } & \multicolumn{2}{|c|}{ Forward } \\
\hline & & Mean & Std. Dev. & Mean & Std. Dev. & Mean & Std. Dev. & Mean & Std.Dev. & Mean & Std.Dev. & Mean & Std.Dev. \\
\hline 1998 & 95,879 & 0.053 & 0.062 & 0.014 & 0.011 & 0.009 & 0.018 & 0.151 & 0.078 & 0.045 & 0.024 & 0.059 & 0.085 \\
\hline 1999 & 103,945 & 0.049 & 0.056 & 0.013 & 0.012 & 0.007 & 0.012 & 0.169 & 0.089 & 0.052 & 0.027 & 0.069 & 0.107 \\
\hline 2000 & 102,465 & 0.049 & 0.053 & 0.013 & 0.011 & 0.009 & 0.019 & 0.182 & 0.094 & 0.058 & 0.030 & 0.076 & 0.118 \\
\hline 2001 & 114,461 & 0.049 & 0.050 & 0.013 & 0.011 & 0.008 & 0.017 & 0.187 & 0.095 & 0.057 & 0.029 & 0.080 & 0.123 \\
\hline 2002 & 122,218 & 0.063 & 0.064 & 0.017 & 0.014 & 0.008 & 0.016 & 0.178 & 0.088 & 0.055 & 0.028 & 0.081 & 0.127 \\
\hline 2003 & 138,158 & 0.070 & 0.075 & 0.018 & 0.018 & 0.013 & 0.038 & 0.177 & 0.083 & 0.056 & 0.027 & 0.085 & 0.130 \\
\hline 2004 & 202,551 & n.a. & n.a. & n.a. & n.a. & n.a. & n.a. & n.a. & n.a. & n.a. & n.a. & n.a. & n.a. \\
\hline 2005 & 194,120 & 0.061 & 0.058 & 0.017 & 0.015 & 0.014 & 0.035 & 0.207 & 0.102 & 0.064 & 0.034 & 0.101 & 0.162 \\
\hline 2006 & 216,924 & 0.054 & 0.054 & 0.015 & 0.014 & 0.015 & 0.045 & 0.214 & 0.103 & 0.069 & 0.034 & 0.102 & 0.153 \\
\hline 2007 & 254,905 & 0.047 & 0.056 & 0.013 & 0.015 & 0.012 & 0.038 & 0.214 & 0.097 & 0.068 & 0.032 & 0.105 & 0.159 \\
\hline
\end{tabular}

Notes: In Table 3-2, we redo the exercise in Table 3-1 based on value-added tax information. The tax data are not available for 2004. 
Table 4 Olley and Pakes Regressions with Contemporaneous Spillover Variables and Tariff Controls: all firms, foreign-invested, domestic firms with zero foreign investment

\begin{tabular}{lccc}
\hline \hline & All firms & Foreign-invested firms & $\begin{array}{c}\text { Domestic firms (0 foreign } \\
\text { share) }\end{array}$ \\
\hline Foreignshare (by HK-Taiwan-Macau) & -0.00379 & 0.000847 & \\
Foreignshare (by other countries) & $(0.00312)$ & $(0.00550)$ & \\
Stateshare & $0.00716^{* *}$ & $0.0131^{* *}$ & \\
& $(0.00342)$ & $(0.00526)$ & 0.000450 \\
Horizontal & $-0.0170^{* * *}$ & 0.00545 & $(0.00351)$ \\
& $(0.00346)$ & $(0.00870)$ & 0.396 \\
Backward & $0.449 * *$ & $0.403 * *$ & $(0.246)$ \\
Forward & $(0.189)$ & $(0.192)$ & 0.867 \\
& 0.989 & $1.152^{* * *}$ & $(1.004)$ \\
lnTariff & $(0.644)$ & $(0.556)$ & $0.744 * * *$ \\
& $0.427 * * *$ & $0.410^{* * *}$ & $(0.224)$ \\
lnTariff on Inputs & $(0.129)$ & $(0.105)$ & 0.0562 \\
& 0.0535 & $0.0800^{*}$ & $(0.0683)$ \\
WTO Dummy & $(0.0483)$ & $(0.0411)$ & 0.0214 \\
& 0.0212 & 0.0354 & $(0.0147)$ \\
Constant & $(0.0139)$ & $(0.0240)$ & $0.315 * * *$ \\
& $0.376 * * *$ & $0.0263 * * *$ & $(0.0288)$ \\
Observations & $(0.0393)$ & $(0.00515)$ & $1.196 * * *$ \\
R-squared & $1.268^{* * *}$ & $1.299 * * *$ & $(0.173)$ \\
\hline
\end{tabular}

Notes: Robust clustered standard errors, clustered at the sector level, are presented in parentheses. The dependent variable lnTFP. Each regression includes firm-fixed effects and year dummies. The dummy is defined as 1 if firm $i$ has non-zero foreign share at period t, 0 otherwise. $A *$ indicates significance at the 10 percent level, a $* *$ indicates significance at the 5 percent level, and a *** indicates significance at the 1 percent level. 


\begin{tabular}{|c|c|c|c|}
\hline$F$-stat $($ Backward $*$ ownership $=0)$ & 2.36 & 1.50 & 2.23 \\
\hline Prob $>F$ & 0.130 & 0.226 & 0.141 \\
\hline Forward*ownership & $\begin{array}{l}-0.123 \\
(0.065)\end{array}$ & $\begin{array}{c}0.062 \\
(0.103)\end{array}$ & $\begin{array}{l}-0.140 \\
(0.066)\end{array}$ \\
\hline$F$-stat $($ Forward $*$ ownership $=0)$ & 3.66 & 0.36 & 4.57 \\
\hline Prob $>F$ & 0.061 & 0.549 & 0.037 \\
\hline$F$-stat (interaction terms jointly zero) & 8.97 & 6.08 & 8.14 \\
\hline Prob $>F$ & 0.0001 & 0.011 & 0.0001 \\
\hline
\end{tabular}

Notes: Robust clustered standard errors are presented in parentheses. The dependent variable for all regression is lnTFP. All regressions include firm fixed effects and year dummies. Ownership is a dummy variable, which equals one if a firm is a SOE and zero otherwise. 
Table 6A: Interaction between Trade and FDI Spillovers Using WTO Entry as Measure of Trade Policy

\begin{tabular}{|c|c|c|c|c|c|c|}
\hline & \multicolumn{2}{|c|}{ All } & \multicolumn{2}{|c|}{ Foreign-invested firms } & \multicolumn{2}{|c|}{ Domestic firms } \\
\hline & Non-SOEs & SOEs & Non-SOEs & SOEs & Non-SOEs & SOEs \\
\hline \multirow[t]{2}{*}{ Horizontal FDI } & $0.430 * *$ & $0.379 * * *$ & $0.426^{* *}$ & -0.751 & 0.338 & \\
\hline & $(0.181)$ & $(0.112)$ & $(0.198)$ & $(0.532)$ & $(0.208)$ & \\
\hline \multirow[t]{2}{*}{ Backward FDI } & 0.499 & -0.259 & 0.486 & $2.977 * * *$ & 0.486 & \\
\hline & $(0.734)$ & $(0.551)$ & $(0.682)$ & $(1.070)$ & $(1.035)$ & \\
\hline \multirow[t]{2}{*}{ Forward FDI } & $0.427 * *$ & 0.272 & $0.325 *$ & $0.638 * *$ & $0.848 * * *$ & \\
\hline & $(0.197)$ & $(0.183)$ & $(0.164)$ & $(0.262)$ & $(0.272)$ & \\
\hline \multirow[t]{2}{*}{ Horizontal*WTO } & 0.0317 & 0.104 & -0.00297 & $0.399 *$ & 0.0685 & 0.105 \\
\hline & $(0.0671)$ & $(0.0816)$ & $(0.0653)$ & $(0.231)$ & $(0.0856)$ & $(0.0824)$ \\
\hline \multirow[t]{2}{*}{ Backward*WTO } & $0.516 * * *$ & $0.812 * * *$ & $0.647 * * *$ & 0.00441 & $0.441 *$ & $0.824 * * *$ \\
\hline & $(0.190)$ & $(0.215)$ & $(0.177)$ & $(0.392)$ & $(0.228)$ & $(0.223)$ \\
\hline \multirow[t]{2}{*}{ Forward*WTO } & 0.00870 & 0.0164 & 0.0800 & -0.101 & -0.113 & 0.00580 \\
\hline & $(0.0883)$ & $(0.0993)$ & $(0.0801)$ & $(0.113)$ & $(0.0875)$ & $(0.100)$ \\
\hline \multirow[t]{2}{*}{ WTO } & $0.106 * * *$ & $0.233 * * *$ & -0.0359 & $0.130 * * *$ & $0.279 * * *$ & $0.234 * * *$ \\
\hline & $(0.0295)$ & $(0.0260)$ & $(0.0231)$ & $(0.0299)$ & $(0.0314)$ & $(0.0263)$ \\
\hline Observations & $1,415,341$ & 125,482 & 344,818 & 2,383 & $1,070,523$ & 123,099 \\
\hline R-squared & 0.171 & 0.101 & 0.182 & 0.250 & 0.161 & 0.100 \\
\hline
\end{tabular}


Table 6B: Interaction between Trade and FDI Spillovers Using Tariffs as Measure of Trade Policy

\begin{tabular}{|c|c|c|c|c|c|c|}
\hline & \multicolumn{2}{|c|}{ All } & \multicolumn{2}{|c|}{ Foreign-invested firms } & \multicolumn{2}{|c|}{ Domestic firms } \\
\hline & Non-SOEs & SOEs & Non-SOEs & SOEs & Non-SOEs & SOEs \\
\hline \multirow[t]{2}{*}{ Horizontal FDI } & 0.299 & 0.480 & 0.499 & -0.418 & -0.0708 & 0.524 \\
\hline & $(0.408)$ & $(0.361)$ & $(0.401)$ & $(0.536)$ & $(0.483)$ & $(0.368)$ \\
\hline \multirow[t]{2}{*}{ Backward FDI } & $1.843^{* * *} *$ & $2.332 * * *$ & $1.434 * *$ & $5.067 * * *$ & $3.162 * * *$ & $2.222 * * *$ \\
\hline & $(0.588)$ & $(0.725)$ & $(0.632)$ & $(0.966)$ & $(0.685)$ & $(0.745)$ \\
\hline \multirow[t]{2}{*}{ Forward FDI } & 0.381 & 0.562 & 0.562 & $0.945 * *$ & 0.0878 & 0.499 \\
\hline & $(0.599)$ & $(0.560)$ & $(0.485)$ & $(0.362)$ & $(0.783)$ & $(0.581)$ \\
\hline \multirow[t]{2}{*}{ WTO } & $0.133 * * *$ & $0.308 * * *$ & $0.0262 * * *$ & $0.201 * * *$ & $0.313 * * *$ & $0.310 * * *$ \\
\hline & $(0.0316)$ & $(0.0236)$ & $(0.00503)$ & $(0.0327)$ & $(0.0297)$ & $(0.0236)$ \\
\hline \multirow[t]{2}{*}{ Tariff*Horizontal FDI } & 0.0700 & -0.0163 & -0.0342 & -0.0830 & 0.211 & -0.0296 \\
\hline & $(0.128)$ & $(0.138)$ & $(0.132)$ & $(0.122)$ & $(0.156)$ & $(0.140)$ \\
\hline \multirow[t]{2}{*}{ Tariff*Backward FDI } & -0.423 & $-0.957 * *$ & -0.210 & $-1.023 * * *$ & $-1.068 *$ & $-0.916 * *$ \\
\hline & $(0.446)$ & $(0.382)$ & $(0.442)$ & $(0.238)$ & $(0.583)$ & $(0.384)$ \\
\hline \multirow[t]{2}{*}{ Tariff*Forward FDI } & 0.0401 & -0.139 & -0.0820 & -0.174 & 0.339 & -0.101 \\
\hline & $(0.303)$ & $(0.254)$ & $(0.238)$ & $(0.130)$ & $(0.405)$ & $(0.262)$ \\
\hline \multirow[t]{2}{*}{ Constant } & $1.284 * * *$ & $1.399 * * *$ & $1.245^{* * *}$ & $1.509 * * *$ & $1.307 * * *$ & $1.390 * * *$ \\
\hline & $(0.200)$ & $(0.0840)$ & $(0.187)$ & $(0.128)$ & $(0.208)$ & $(0.0844)$ \\
\hline Observations & $1,415,341$ & 125,482 & 344,818 & 2,383 & $1,070,523$ & 123,099 \\
\hline R-squared & 0.171 & 0.099 & 0.180 & 0.251 & 0.164 & 0.099 \\
\hline
\end{tabular}

Notes: All specifications include firm fixed effects and year dummies. Robust standard errors clustered at sector level. WTO is a dummy equal to 1 from 2002 onwards. Interaction terms are sectoral FDI measures interacted with tariffs. Other controls also included from previous tables but not reported here (firm level FDI and SOE shares, input and final goods tariffs). 
Table 7 Olley and Pakes Regressions for Grouped Data with Contemporaneous Subsidized and non-Subsidized Spillover Variables and Tariff Controls: non-SOEs vs. SOEs (All firms, foreign-invested, and domestic firms with zero foreign investment

\begin{tabular}{|c|c|c|c|c|c|c|}
\hline & \multicolumn{2}{|c|}{ All } & \multicolumn{2}{|c|}{ Foreign-Invested Firms } & \multicolumn{2}{|c|}{ Domestic Firms } \\
\hline & Non-SOEs & SOEs & Non-SOEs & SOEs & Non-SOEs & SOEs \\
\hline \multirow[t]{2}{*}{ horizontals } & $0.347 *$ & $0.367 * *$ & 0.268 & -0.636 & 0.384 & $0.373 * *$ \\
\hline & $(0.206)$ & $(0.164)$ & $(0.195)$ & $(0.543)$ & $(0.247)$ & $(0.164)$ \\
\hline \multirow[t]{2}{*}{ backwardS } & $1.287 *$ & $2.193 * * *$ & 0.780 & $3.807 * * *$ & $1.838 * *$ & $2.115^{* * *}$ \\
\hline & $(0.701)$ & $(0.707)$ & $(0.564)$ & $(0.905)$ & $(0.908)$ & $(0.727)$ \\
\hline forwardS & -0.0673 & 0.0322 & 0.0651 & $0.672 * *$ & -0.0875 & 0.0513 \\
\hline \multirow[t]{2}{*}{ horizontalNS } & $0.520 * *$ & $0.271 *$ & $0.547 * *$ & -0.545 & 0.336 & $0.290 *$ \\
\hline & $(0.228)$ & $(0.146)$ & $(0.221)$ & $(0.397)$ & $(0.289)$ & $(0.147)$ \\
\hline \multirow[t]{2}{*}{ backwardNS } & 0.889 & -0.991 & 1.931 & $2.949 * *$ & -0.0909 & -0.941 \\
\hline & (1.358) & $(0.864)$ & $(1.205)$ & $(1.327)$ & (1.687) & $(0.864)$ \\
\hline \multirow[t]{2}{*}{ forwardNS } & $1.030 *$ & $0.716^{*}$ & $0.803 * *$ & $0.618 * * *$ & $1.694 * *$ & $0.741 *$ \\
\hline & $(0.543)$ & $(0.385)$ & $(0.391)$ & $(0.218)$ & $(0.790)$ & $(0.394)$ \\
\hline Observations & $1,415,341$ & 125,482 & 344,818 & 2,383 & $1,070,523$ & 123,099 \\
\hline$F$-stat $(\mathrm{HS}=\mathrm{HNS})$ & 0.67 & 0.23 & 2.27 & 0.09 & 0.03 & 0.16 \\
\hline Prob $>F$ & 0.416 & 0.635 & 0.138 & 0.768 & 0.86 & 0.687 \\
\hline$F$-stat $(\mathrm{BS}=\mathrm{BNS})$ & 0.06 & 8.36 & 0.64 & 0.57 & 1.17 & 7.42 \\
\hline Prob $>F$ & 0.81 & 0.005 & 0.427 & 0.454 & 0.284 & 0.008 \\
\hline$F$-stat $(\mathrm{FS}=\mathrm{FNS})$ & 1.71 & 1.23 & 1.44 & 0.05 & 2.41 & 1.21 \\
\hline Prob $>F$ & 0.196 & 0.272 & 0.236 & 0.821 & 0.126 & 0.276 \\
\hline$F$-stat (three conditions jointly) & 2.11 & 4.29 & 3.24 & 0.2 & 1.58 & 3.9 \\
\hline Prob $>F$ & 0.109 & 0.008 & 0.028 & 0.895 & 0.205 & 0.0131 \\
\hline
\end{tabular}


Table 8 Olley and Pakes Regressions for Grouped Data with Contemporaneous Subsidized and non-Subsidized Spillover Variables (calculated based on value added tax) and Tariff Controls: non-SOEs vs. SOEs (all firms, foreign-invested, domestic firms)

\begin{tabular}{|c|c|c|c|c|c|c|}
\hline & \multicolumn{2}{|c|}{ All firms } & \multicolumn{2}{|c|}{ Foreign-invested firms } & \multicolumn{2}{|c|}{ Domestic firms } \\
\hline & non-SOEs & SOEs & non-SOEs & SOEs & non-SOEs & SOEs \\
\hline \multirow[t]{2}{*}{ horizontalS } & $0.727 * *$ & $0.856 * * *$ & $0.590 * *$ & -0.601 & $0.797 *$ & $0.892 * * *$ \\
\hline & $(0.303)$ & $(0.267)$ & $(0.236)$ & $(0.470)$ & $(0.454)$ & $(0.270)$ \\
\hline \multirow[t]{2}{*}{ backwardS } & -0.690 & 0.533 & -0.377 & $3.234 * * *$ & -0.866 & 0.440 \\
\hline & $(1.145)$ & $(0.961)$ & $(0.854)$ & $(1.069)$ & $(1.815)$ & $(0.991)$ \\
\hline \multirow[t]{2}{*}{ forwardS } & 0.229 & $0.424 *$ & 0.499 & $0.669 * * *$ & -0.0625 & $0.394 *$ \\
\hline & $(0.425)$ & $(0.235)$ & $(0.349)$ & $(0.216)$ & $(0.490)$ & $(0.228)$ \\
\hline \multirow[t]{2}{*}{ horizontalNS } & 0.275 & $0.299 * * *$ & 0.267 & -0.624 & 0.175 & $0.308 * * *$ \\
\hline & $(0.167)$ & $(0.112)$ & $(0.183)$ & $(0.530)$ & $(0.191)$ & $(0.112)$ \\
\hline \multirow[t]{2}{*}{ backwardNS } & $1.813^{* *}$ & 0.334 & $1.928 * *$ & $3.195 * *$ & 1.659 & 0.293 \\
\hline & $(0.817)$ & $(0.664)$ & $(0.784)$ & $(1.309)$ & $(1.065)$ & $(0.668)$ \\
\hline \multirow[t]{2}{*}{ forwardNS } & $0.485^{* *}$ & 0.258 & $0.385^{* *}$ & $0.676 * *$ & $0.929 * * *$ & 0.292 \\
\hline & $(0.228)$ & $(0.179)$ & $(0.179)$ & $(0.285)$ & $(0.331)$ & $(0.187)$ \\
\hline Observations & $1,222,322$ & 116,138 & 298,385 & 2,308 & 923,937 & 113,830 \\
\hline R-squared & 0.184 & 0.105 & 0.203 & 0.228 & 0.170 & 0.104 \\
\hline$F$-stat $(\mathrm{HS}=\mathrm{HNS})$ & 3.44 & 4.71 & 4.1 & 0.01 & 2.54 & 4.9 \\
\hline Prob $>F$ & 0.069 & 0.0341 & 0.0473 & 0.93 & 0.116 & 0.031 \\
\hline$F$-stat $(\mathrm{BS}=\mathrm{BNS})$ & 3.37 & 0.03 & 3.66 & 0 & 1.96 & 0.02 \\
\hline Prob $>F$ & 0.0714 & 0.854 & 0.061 & 0.98 & 0.167 & 0.896 \\
\hline$F$-stat $(\mathrm{FS}=\mathrm{FNS})$ & 0.17 & 0.19 & 0.05 & 0 & 1.01 & 0.07 \\
\hline Prob $>F$ & 0.683 & 0.663 & 0.817 & 0.98 & 0.21 & 0.786 \\
\hline$F$-stat (three conditions jointly) & 20.02 & 4.27 & 3.15 & 0 & 1.02 & 4 \\
\hline Prob $>F$ & 0.121 & 0.009 & 0.031 & 0.99 & 3.884 & 0.012 \\
\hline
\end{tabular}


Table A-1. Summary of Estimated Coefficients on Input Variables using the Olley Pakes Two Stage Procedure

Foodstuffs

Manufacture of beverages

Manufacture of Tobacco

Manufacture of Textiles

Manufacture of textile wearing apparel, footwear

Manufacture of leather, fur, feather

Processing of timber, manufacture of wood, bamboo

Manufacture of furniture

Manufacture of paper and paper products

Manufacture of articles for culture, education and sports

Processing of petroleum, coking, nuclear fuel

Manufacture of raw chemical materials, chemical products

Manufacture of medicines

Manufacture of chemical fibers

Manufacture of Rubber

Manufacture of Plastics

Manufacture of non-metallic mineral products

Smelting and pressing of non-ferrous metals

Smelting and pressing of metals

Manufacture of metal products

Manufacture of special purpose machinery

Manufacture of transport equipment

Manufacture of electrical machinery and equipment

Manufacture of communication, computers and other electronic equipment

Manufacture of measuring instruments, machinery for cultural activity, office work

Manufacture of artwork and other manufacturing

Total: Across All Sectors
All Enterprises

\begin{tabular}{|c|c|c|c|c|c|}
\hline \multirow{2}{*}{\multicolumn{3}{|c|}{ Materials }} & \\
\hline & Materials & Capital & Labor & Materials & Capital \\
\hline 0.063648 & 0.795382 & 0.039528 & 0.046787 & 0.846505 & 0.037731 \\
\hline 0.062011 & 0.797568 & 0.039427 & 0.060272 & 0.783996 & 0.038303 \\
\hline 0.072545 & 0.793483 & 0.00697 & 0.108622 & 0.699906 & 0.006198 \\
\hline 057483 & 0.8192 & 0.041548 & 0.047518 & 0.834871 & 0.048671 \\
\hline 097813 & 0.706444 & 0.056324 & 0.073357 & 0.742437 & 0.060367 \\
\hline 082379 & 0.795421 & 0.043285 & 0.065043 & 0.844919 & 0.042856 \\
\hline 056418 & 0.814447 & 0.041392 & 0.041642 & 0.859254 & 0.039784 \\
\hline 110771 & 0.761009 & 0.050201 & 0.10054 & 0.774004 & 0.053424 \\
\hline 056664 & 0.808117 & 0.048015 & 0.048811 & 0.812315 & 0.055325 \\
\hline 109501 & 0.727006 & 0.033724 & 0.067636 & 0.79291 & 0.02737 \\
\hline 0.10447 & 0.774527 & 0.0155 & 0.092348 & 0.784275 & 0.005467 \\
\hline 0.067949 & 0.790304 & 0.033636 & 0.065466 & 0.792625 & 0.036906 \\
\hline 0.086851 & 0.762153 & 0.070223 & 0.0884 & 0.763997 & 0.079882 \\
\hline 0.053973 & 0.892586 & 0.035822 & 0.065075 & 0.906072 & 0.018944 \\
\hline 0.092509 & 0.718883 & 0.057499 & 0.077012 & 0.723723 & 0.06136 \\
\hline 0.126058 & 0.697807 & 0.038696 & 0.106281 & 0.696002 & 0.054243 \\
\hline 0.050259 & 0.814683 & 0.03636 & 0.043229 & 0.821056 & 0.042961 \\
\hline 0.041025 & 0.862236 & 0.029997 & 0.041844 & 0.863016 & 0.033199 \\
\hline 0.10535 & 0.750012 & 0.013021 & 0.110405 & 0.73531 & 0.007556 \\
\hline 115651 & 0.683249 & 0.051367 & 0.10836 & 0.6673 & 0.055312 \\
\hline 075696 & 0.786973 & 0.046593 & 0.072163 & 0.806896 & 0.052035 \\
\hline 0.09118 & 0.792991 & 0.066821 & 0.082191 & 0.814969 & 0.070575 \\
\hline 0.106034 & 0.774765 & 0.046943 & 0.086655 & 0.796434 & 0.051404 \\
\hline 207143 & 0.70811 & 0.046657 & 0.159348 & 0.729829 & 0.042883 \\
\hline 0.135264 & 0.726912 & 0.042837 & 0.089397 & 0.764966 & 0.052725 \\
\hline 072451 & 0.778526 & 0.034818 & 0.056781 & 0.804089 & 0.035706 \\
\hline 085971 & 0.773345 & 0.043454 & 0.071651 & 0.789283 & 0.047174 \\
\hline
\end{tabular}




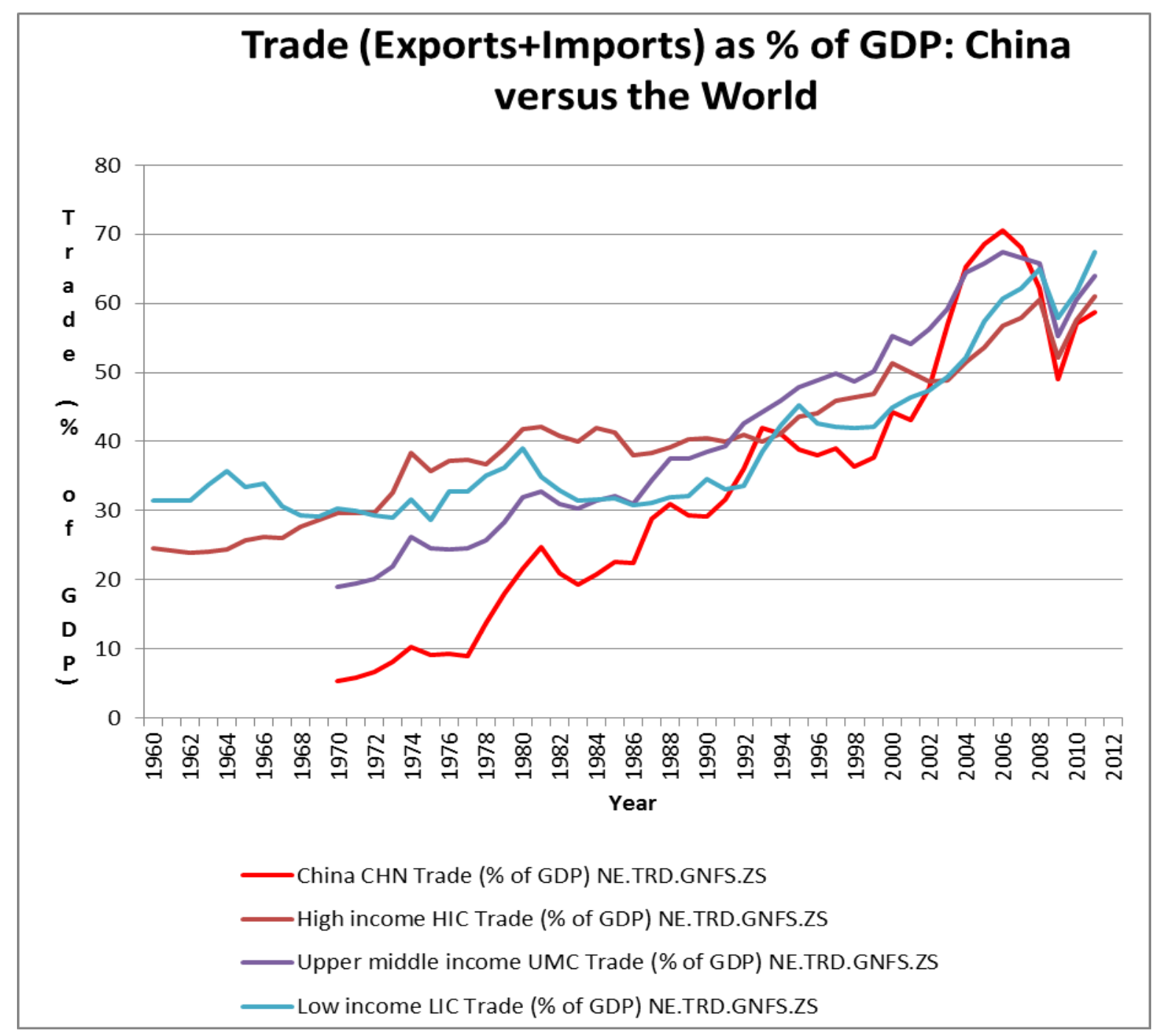

Figure 1 
Figure 2

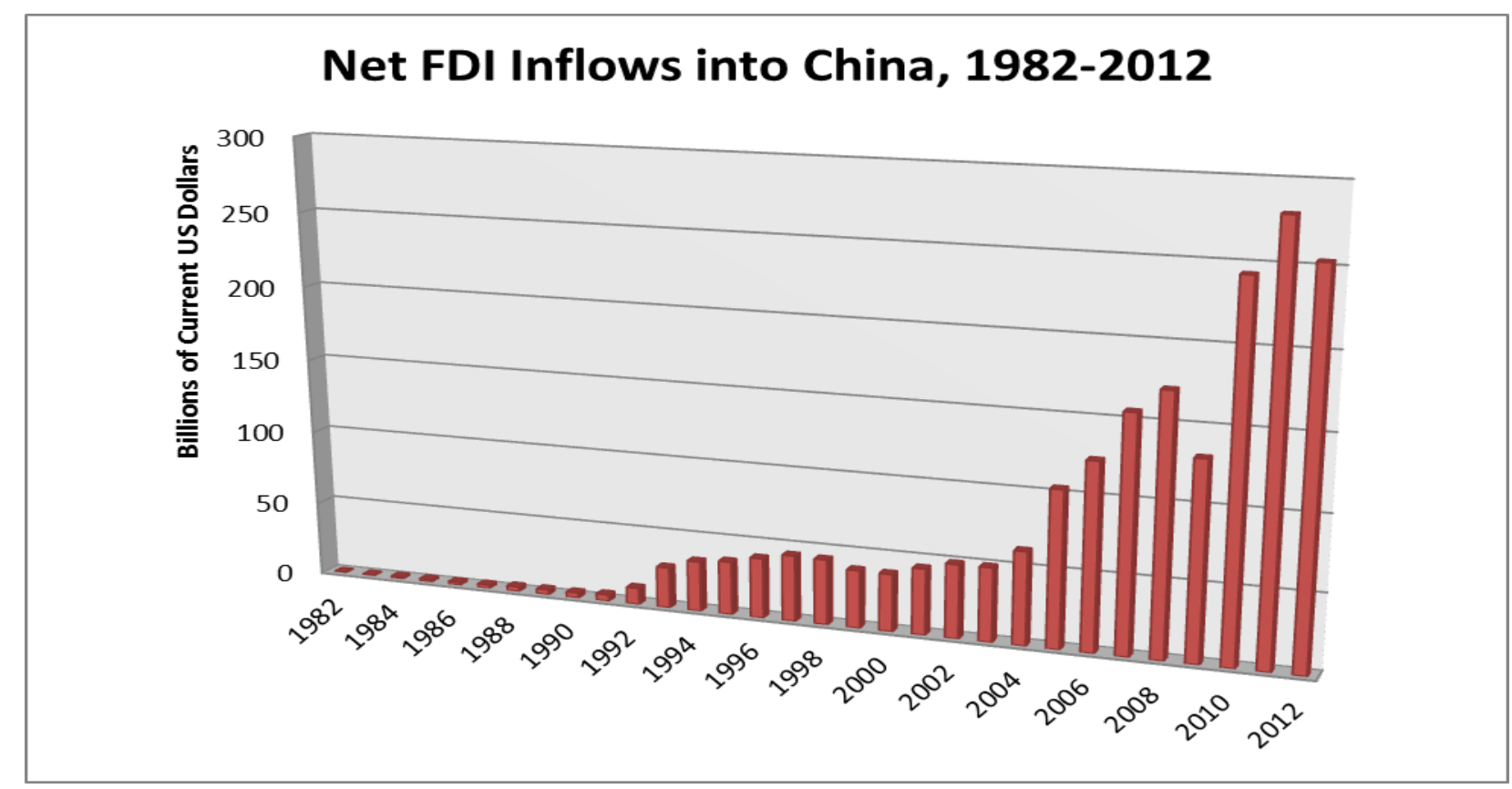


Figure 3. Tax Rate Distribution with Groups of firms (2004)

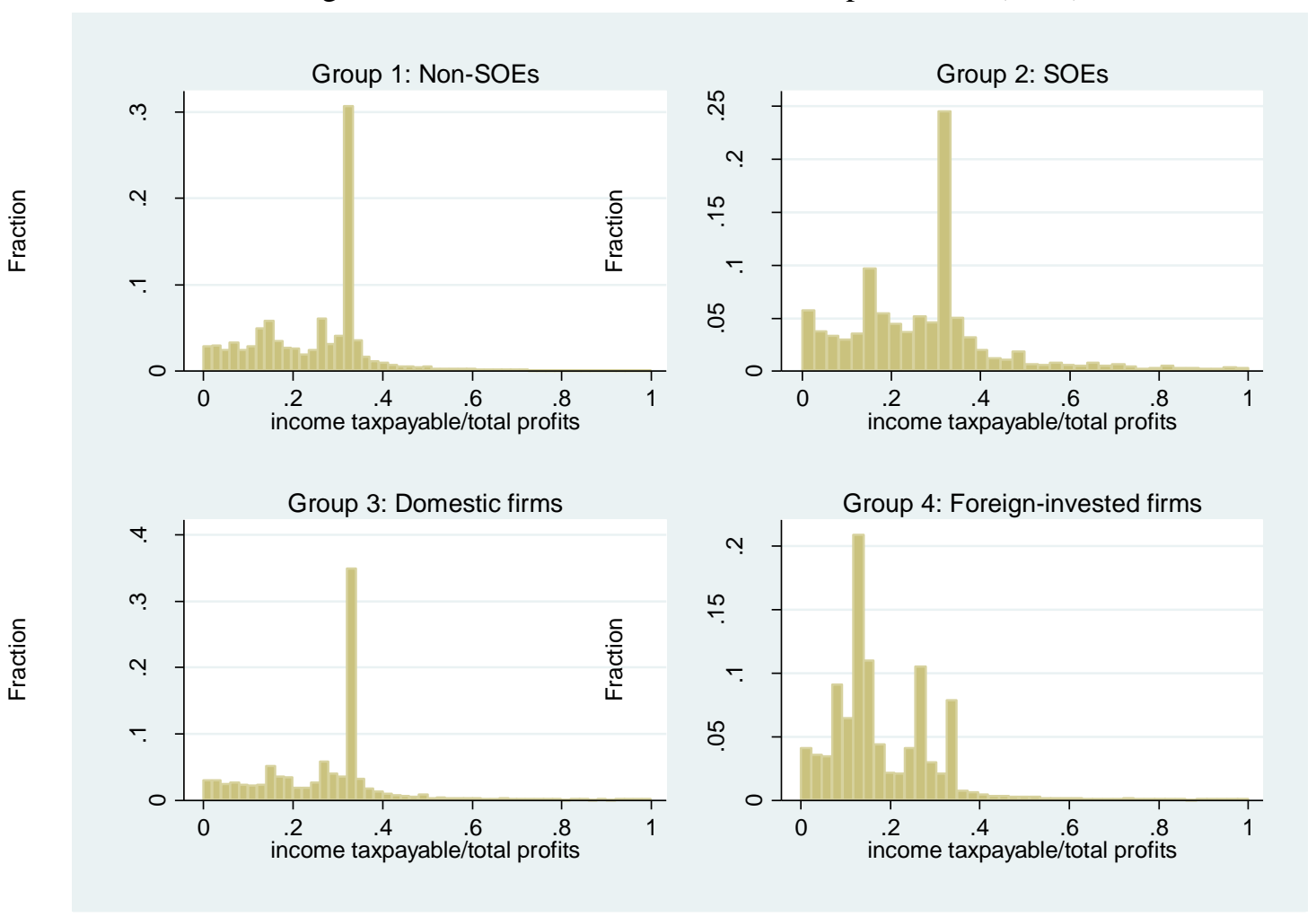


Figure 4. Initial Tariffs and Subsequent Tariff Changes

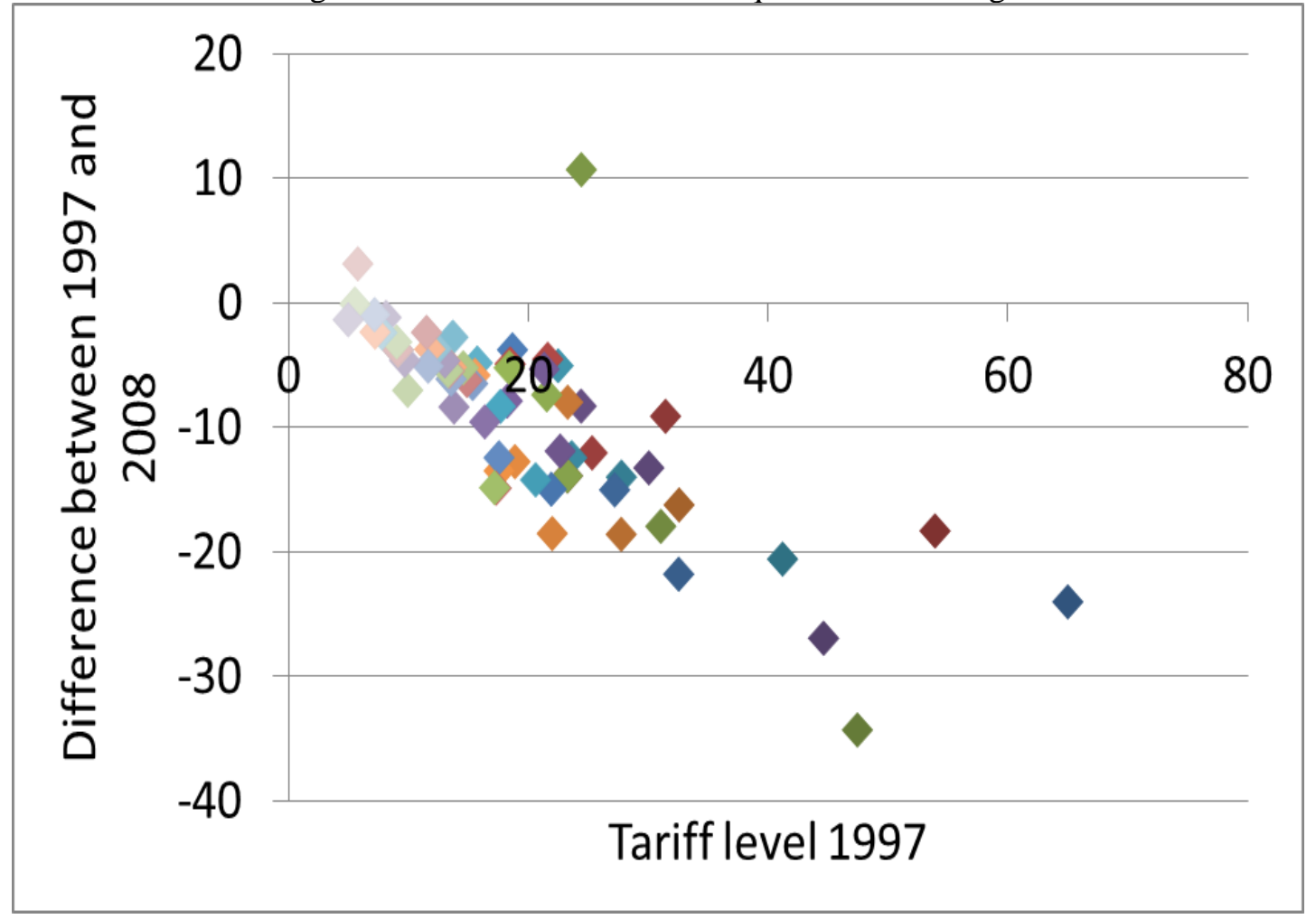


